\title{
Changes in Employed People's Health Satisfaction
}

\author{
Monika Jungbauer-Gans, Gerhard Krug
}

\begin{abstract}
The article examines for Germany whether the subjective satisfaction with health has changed over the course of time. It is analysed whether a drop in health satisfaction can be observed and whether this can be explained by changing employment circumstances. Labour market research has documented a change in the employment situation in detail, which can be subsumed under the keyword of precarisation. In the theoretical section we will portray the current state of research concerning the development of the employment situation and emphasize the significance of gainful employment for health. The empirical analyses of the article are based on data of employed people in the German Socio-Economic Panel Study (SOEP) of the years 1985, 1996 and 2009. The data show a significantly declining health satisfaction between 1985 and 2009 in Western Germany and no noteworthy change in Eastern Germany between 1996 and 2009. The Blinder/Oaxaca decomposition is used in the analyses to better differentiate the effect of the changed employment situation on the drop in health satisfaction. The analyses indeed reveal changing effects of the employment situation. In Western Germany, a significant percentage of the lesser health satisfaction can be attributed to an increasing number of workers in precarious employment situations. Workplace security is of primary significance for explaining the declining health satisfaction in Western Germany.
\end{abstract}

Keywords: Satisfaction with health · Precarious employment $\cdot$ Change

\section{Introduction}

The profound changes that have arisen in the course of modernisation processes and social development have led to a variety of economic, technological and medical advances, which resulted in an improvement of living conditions and hygiene and thus to a prolonged life expectancy. In a continuation of this long-term trend, life expectancy at birth in the EU states rose from 1990 until 2006 from an average 73.1 years to 75.6 years (WHO 2010). A study of life expectancy in Germany shows that 
rising levels of education are accompanied by a drop in the risk of disease incidence (Unger 2003). The mortality trend in Germany in the past century is particularly characterised by an extreme decline in infant mortality to only 1 percent of the risk of the year 1871, while the higher age cohorts show a more moderate decline which decreases steadily with increasing age (Dinke/ 2002). In country comparisons, the national income and the productivity of the health system - measured via health costs - have been identified as central influencing factors on health and life expectancy. The example of the CIS states, with a considerable decline in life expectancy in the early 1990s, indicates that the socio-economic conditions and the health behaviour (in this case alcohol consumption in particular) have a considerable importance for health and life expectancy. A prolonged life expectancy is accompanied by a shift in the disease spectrum towards a greater prevalence of chronic diseases such as cancer and cardiovascular-diseases (Maaz et al. 2007). While total life expectancy increases, it is debated whether the shift in the diseases spectrum to chronic diseases has also increased the so-called "active" life expectancy, or the duration without any serious restrictions to health. In an international comparison, Unger (2003) shows that in Germany the years of inactivity also decrease along with an increasing life expectancy, while in the USA growing life expectancy is accompanied by a rise in the number of inactive years. Since today we must focus more strongly on mortality in the middle and higher ages than on infant mortality for the continued prolongation of life expectancy, social determinants of health are gaining significance (Klein 2001).

The health developments can also be examined under a life-course perspective: What mechanisms are at work over the life course and during various life phases? Do burdens accumulate to cause a rise in social differences in health? One study investigating the question of whether social differences in health increase, remain constant or lessen over the life course concludes that for most observed health indicators, a divergence is apparent between people with low and high levels of education. With increasing age, constant educational differences are only found in assessments of subjective health, the number of chronic diseases and in memory ability, and even decreasing educational differences in the rate of speaking (Leopold/ Engelhardt 2011). The authors explain the predominantly divergent patterns with the accumulation theory after which early advantages grow systematically.

This article focuses on the development of subjective satisfaction with health. A number of studies show that self-assessed health satisfaction has high predictive validity for the mortality forecast regardless of the objective state of health (cf. Idler/Benyamini 1997; Ferraro/Farmer 1999). The demographic change of the population of Germany is characterised by a drop in the numbers of younger and a rise in the numbers of older people. The analyses of health satisfaction in this article are restricted to employed people between the ages of 20 and 65 years; therefore, this demographic effect on health satisfaction is only of significance to the extent in which the ratios of age cohorts shift among the over-20 and under-65-year-old employed people. Processes that can result in a changed age structure among employed people include a later entry into the job market among younger people due to higher levels of educational attainment, decreasing age cohorts among younger 
people over the course of time due to dropping birth rates, changing employment behaviour or re-entry in the labour market (primarily by women during and after raising a family) or a lengthening of the actual working lifetime of older people due to later retirement.

The characteristics of the work situation are relevant for the subjective health of employed people. The changes in employment structures coined as tertiarisation lead to changing work-related stress. As a result of technological developments and successful occupational safety measures, activities that are a physical strain and harm caused by hazardous substances at the workplace are in decline, while stress and time pressure are at a rise. Moreover, the composition of groups of people affected by occupational stress is changing. Additionally, labour market sociologists are discussing the increasing insecurity of employment relationships resulting from fixed-term and temporary agency work as well as (the threat of) unemployment. Yet analyses also reveal that health disparity within countries is greater than that between countries (WHO 2010). Differences can mainly be identified along socioeconomic indicators such as relative poverty, unemployment and migration backgrounds.

In this article we examine the following questions: (1) How does the subjective health satisfaction of employed people change over the course of time? Existing sociological health studies that examine the change of subjective health or health risk factors in general use age-standardised data (e.g. Krol/ 2010). However, age standardisation masks the picture from the perspective of an organisation in which the workforce changes successively. We therefore examine the non-age-standardised development in the descriptive section. (2) What contribution do changes in the occupational composition make to the development of subjective health satisfaction? (3) Are there changes in the significance of social determinants of health satisfaction? The latter two aspects can be differentiated using a decomposition analysis according to Blinder (1973) and Oaxaca (1973), which separates the influence of structural changes over time from other effects that reflect the influence of different determinants (as well as that of unobserved heterogeneity). Data from the German Socio-Economic Panel Study (SOEP) is used for the analyses. They are then conducted separately for Western and Eastern Germany as both the development of health (cf. RKI 2009) and of the labour market differentiate considerably in East and West. ${ }^{1}$ Hence, this article pursues a macro-structural question of clarifying whether long-term changes in the health satisfaction of the population are the result of structural changes in working life or of a changing significance in work-related determinants of health over time. The Blinder/Oaxaca decomposition offers the major advantage of separating these two aspects.

1 A detailed report by the Robert Koch Institute (RKI 2009) of the development of health in the East and West over the course of 20 years following the fall of the wall comes to the conclusion that the health situations in Eastern and Western Germany have largely approximated, hence no considerable differences exist today. Regional differences arise rather along the dividing lines of wealth and poverty. For children and young people, educational opportunities and social circumstances in particular are of significance for health. 


\section{Current state of research}

In the empirical section of the article, we examine in which way structural changes on the labour market contribute to the development of health satisfaction in Germany. We will therefore give an overview of the current state of research from relevant scientific findings concerning the change of employment in this section. We will then go into the connection between precarious employment conditions and health.

\section{Change in the employment situation}

In past years, labour market sociologists have discussed whether precarious employment is on the rise (Struck et al. 2007), seeing it as a result of changes in the ratio of supply and demand on the labour market, the transnationalisation of the economy, the increase in location- and time-independent services, changed legal and institutional circumstances (protection against dismissal) and changed employment interests by employees. The study by Struck et al. (2007) comes to the conclusion that lessened employment stability can be empirically confirmed, which is explained primarily by the relative growth of the service sector. Since the probability of direct company transfer is high, in spite of greater fluctuation this does not lead to any strikingly greater employment uncertainty. From the perspective of employee representatives these developments are also discussed critically under the headings of "erosion of the standard employment relationship" (Hoffmann/Walwei 1998) or "flexibilisation of the labour market." A "standard employment relationship" is understood as indefinite, full-time dependent employment with regular daytime, weekday working hours. Empirical studies have examined whether so-called "atypical" jobs have increased. These include fixed-term work, temporary agency work, part-time work, irregular or unusual working hours and self-employment. Studies that quantify the ratio of standard employment to other jobs ascertain that the percentage of standard employment relationships dropped from 68 percent in 1995 to 62 percent in 2005, but that they continue to predominate (Giesecke 2006; cf. also Eichhorst et al. 2010). Only a small amount of dependent employees are subjected to fixed-term contracts. The rate rose from 1996 to 2010 from approx. 5 percent to 9 percent and is higher for women than for men. This is a projected 1.3 million to 2.5 million employees in Germany (Gundert/Hohendanner 2011). People with medium skill levels are found less often in fixed-term employment (Giesecke 2006). In the public sector an above-average number of employment relationships are fixed-term. Contrary to expectations, the percentage of fixed-term employment contracts is therefore relatively independent of economic developments (Hohendanner 2010).

From 1996 until 2010, the percentage of fixed-term and temporary agency workers rose from 0.6 percent to 2.9 percent (Gundert/Hohendanner 2011). If we look at the age structure of temporary agency workers, we see that the number of 20 to 30 -year-olds is disproportionately high (Jahn/Rudolph 2002). The relative decline in standard employment relationships is mainly the result of increasing parttime work. Part-time work is distributed unequally among economic sectors. While 
standard employment relationships are typical in industry, there are fewer permanent full-time positions in the services sector (Eichhorst et al. 2010). Part-time work is a domain of women. From the age of 35 years, approximately half of all employed women are part-time employees, but only 5 percent of the men (Kock 2008). In the year 2009, 24 percent of employees worked on Saturdays and 12 percent on Sundays in Germany, which is repeatedly put to discussion by certain social groups and is relatively high in an international comparison (Eichhorst et al. 2010). Roughly 18 percent of employed people work in shifts, 26 percent in evening shifts and 10 percent in night shifts.

Another form of "atypical" work is freelance work, particularly when it is carried out in fields that are commonly occupied by salaried staff. These types of work are also categorised among disguised employment if they are bound by instructions and carried out within the organization of the employer. Since 1999 the Disguised Employment Act (Scheinselbständigkeitsgesetz) (Article 7 SGB IV) aims to prevent this. The self-employed with no employed staff of their own are described as "solo self-employed people." More than half of all self-employed people and therefore 5.4 percent of all employed people or 2.3 million individuals are included in this category (Kock 2008).

In summary, we can state that "atypical" employment has increased to a moderate degree. Although it cannot be clarified conclusively whether these employment relationships do not also meet employee interests - this is more likely in the case of part-time work - we can assume that they are rather disadvantageous for employees (Giesecke 2006). Employees in atypical employment relationships are subjected to a greater risk of precariousness in particular with regard to wages; part-time and marginal employees have lesser opportunities to take part in advanced training (Brehmer/Seifert 2008). The example of disguised employment reveals that employers increasingly pass on the risks of employment such as illness or bad order situation to the employed people and save expenses for employer contributions to social security. In particular teenagers and young adults are affected by tendencies to precarisation during their transition from training to employment (Kock 2008).

\section{What significance does the employment situation have for health?}

The employment situation has effects on health both because of the material circumstances linked to it and the typical burdens and resources of the specific vocational field. The employment situation is a primary source of the material situation of a family and can therefore lead to individual deprivation, which contributes to higher exposition to stress factors in the family and living environment.

Siegrist and Theorell (2006) emphasize the significance of mental stress caused by work situations. Not merely physically stressful working conditions such as physical and toxic stress, long or irregular working hours, akinesic work or health-damaging physical positions affect health. Particularly, the uncertainty resulting from precarious employment situations such as informal work that is not legally secured lead to mental stress (Mannila 2012). The demand-control model (Karasek 1979; Karasek/Theorell 1990) and the effort-reward-imbalance model (Siegrist et al. 1986; 
Siegrist 1996) describe how mental stress arises from the employment situation. The demand-control model assumes that jobs characterised by high demands, low control possibilities and a lack of social support give rise to particularly high stress levels, while the effort-reward-imbalance model is based on reciprocity expectations. It argues that rewards such as income, appreciation, career opportunities and employment security must be in a proper balance with performance if they are not to lead to mental burdens or stress. In occupations with a higher level of psychosocial stress, there is a higher risk of early retirement caused by illness (Dragano 2007). A review of prospective empirical studies and physiological and biochemical studies (Siegrist/Theorel/ 2006) shows that such stressful work situations correlate with poor health, in particular cardiovascular-diseases (cf. also Peter 2006). The summary of available prospective and experimental studies on the effects of these disparities reveals a considerably increased risk of coronary and cardiovascular diseases as well as symptoms of depression (Siegrist/Dragano 2008).

Since the health behaviour of people of lower socio-economic status is less health-oriented, their occupational situation also affects their health via this mechanism (Siegrist 1989; Nocon et al. 2007; Helmert/Schorb 2009). It has been proven that the work situation itself, in the form of shift work, high risk exposition and physical stress also correlates with health behaviour, in particular with smoking and lack of exercise or alcohol abuse, while autonomy in the job promotes physical activity (Johansson et al. 1991; Yang et al. 2001; cf. also Lampert et al. 2005).

The availability of material, personal and social coping resources correlates with the employment and income situation. Health-relevant deficiencies occur mainly among those affected by poverty or threatened circumstances (Lampert 2011). However, personal resources such as health-related knowledge (Reibling/Wendt 2010), control convictions (Janßen et al. 2000) or a sense of coherence (Wydler et al. 2006), which might be influenced by occupational and social situations, also play a major role. Finally, the occupational situation can, in some cases, also be linked to poorer health care because people of lower social strata tend to make more morbidity-induced and lesser preventive use of medical services. A greater social distance between medical staff and patients can lead to communication problems or fears to seek doctors out (summarised in Jungbauer-Gans 2002).

Moreover, we can assume that a regional context can generate burdens through low resources (low prosperity level of the immediate environment) and high stress (e.g. higher crime rate, environmental burdens from pollution) or through a high degree of social disparities and hence a more salient structure of inequality or more extensive relative deprivation (cf. Wilkinson 1996; Wilkinson/Marmot 2003; Wilkinson/Pickett 2006).

While these factors imply the influence of the social situation on health, another delimited thesis presumes selection processes as a result of the state of health: social advancement among the healthy or social descent among the ill explain the social gradients of health (cf. in summary Richter/Hurrelmann 2006). The research that attempts to quantify this reversed causal effect comes to the conclusion that health-related social descent is less relevant than the reversed mechanism (Mackenbach 2006; Lahelma 2006). The question of the direction of a causal influence has 
also long been the basis of research of the reciprocal effects between the experience of unemployment and health. ${ }^{2}$ While some of the research has been able to confirm a causal effect of the experience of unemployment on health, there is also evidence of a reversed selection effect, which cites a greater unemployment risk among ill or disabled people (e.g. Böckerman/IImakunnas 2009, who use Finnish panel data and matching methods; cf. in summary Hollederer 2008, 2011). An American longitudinal study that examines the effects of involuntary unemployment on health after controlling for health-related selection and other third variables comes to the conclusion that unemployment following a life-threatening illness leads to very negative effects on subjective health and an increase in symptoms of depression (Burgard et al. 2007). Unemployment for other reasons has far lesser effects on symptoms of depression as well as on subjective health. In order to exclude the effect of unemployment selectivity, some studies investigate whether unemployment resulting from shutdowns also leads to poorer health (Browning et al. 2006; Salm 2009; Schmitz 2010). They come to the conclusion that unemployment following an exogenously related loss of work has no negative consequences on health.

The numbers of employees in precarious jobs is rising due to structural changes on the labour market described above. Precarious employment situations can result in increased health burdens. A worldwide report for the WHO states, "Social inequalities due to employment relations represent an enormous social and public health burden" (Benach et al. 2007). Since discontinuities in employment biographies, social descent and reduced control over living situations are frequent consequences of precarious employment, the employment situation can lead to intensified mental stress (Siegrist/Dragano 2008). In a research overview, Oppolzer (2010) shows how prolonged working hours, frequent interruptions by phone calls and emails, night shifts, shift work, as well as precarious jobs such as temporary agency work, fixed-term jobs or disguised employment can result in increased stress and chronic fatigue. Employed people with irregular working hours and on shift work are more frequently ill or have accidents (Lampert et al. 2005). Health insurance data reveal that the mortality rate is determined by a people's relative position in the labour market (cf. in summary Lampert et al. 2005).

Individual studies examine specific forms of precarious employment or specific employment fields, showing that the subjective feeling of social participation is far lower in cases of temporary agency work and even lower in unemployment (Gundert/Hohendanner 2011). Precarious jobs, i.e. catering services provided without a permanent employment contract, marked by a shift between long and short working hours, a situation which cannot be influenced by the employees, lead to familial and health problems such as sleep disorders, fatigue and irregular diets and exercise (Bohle et al. 2004). Yet another study that investigates work in call centres and in software development found that work on weekends, taking work home as well as working overtime correlate with stress and feelings of exhaustion (Hyman

2 Cf. the overview of research concerning the correlation between unemployment and health in the anthology edited by Kieselbach and Mannila (2012). 
et al. 2003). If financial concerns are linked to the employment situation, this leads to poorer mental health (cf. the study on women in precarious jobs in Great Britain by O'Campo et al. 2004). A Spanish study showed that the type of work organisation explains the correlation between social class and subjective health assessment (Borrell et al. 2004). This study provided evidence that precarious employment and high job insecurity are highly associated with physical and psychosocial stress at the workplace. One phenomenon of organisational structural change is the reduction of the workforce (downsizing) due to the removal of production sites or rationalisation. Downsizing increases demands on and time pressure of the employees remaining with the company. In particular in combination with work-related stress resulting from a disparity between effort and reward ("effort-reward imbalance"), the number of reported disease symptoms such as depression, anger, resignation or obsessions is higher (Dragano et al. 2005; Dragano/Siegrist 2012; Otsuka et al. 2012). The lower the social strata, the greater employed people are affected by psychosocial stress at the workplace, which has negative effects on subjective health and correlates with the occurrence of depression (Siegrist et al. 2009). This study furthermore shows that the institutional context is also of significance: under the basic circumstances of southern European and conservative welfare states, psychosocial stress occurs more often than in Scandinavian countries with social-democratic welfare systems. Nolte and McKee (2004) deal with the influence of growing income disparity in Western and Eastern Germany on subjective health. Using SOEP data they reach the conclusion that income disparity has increased in both regions. While in the West the influence of income on health has risen, the coefficients lost significance in the East, where education is a more important determinant of subjective health.

In summary, we can state that studies have already used microdata to examine the correlation between employment conditions and health. In some of these studies the changing significance of the health determinants were investigated by comparing coefficients in regression models. However, none of the work has looked at the significance of characteristics of the work situation in relation to socio-demographic and non-observed variables. This article intends to close this research gap. In the next section, we will describe the data and methods used to separate the significance of structural changes of the labour market for the change in health satisfaction.

\section{Data and methods}

The German Socio-Economic Panel Study (SOEP) is the data basis of our analysis. The SOEP is an annual, representative tracking survey. The survey was begun in 1984 in Western Germany, covering the German population as well as households of foreigners residing in Germany. Since 1990 the SOEP has been supplemented by a survey in Eastern Germany. The purpose of later sample supplements that were independent of the original samples was to take the change in the population, for instance through immigration, into consideration. In this analysis, we use all partial 
samples of the SOEP. ${ }^{3}$ We limit our analysis to gainfully employed people between the ages of 20 and 65.

The explanandum of the presented analysis are changes in the state of health of employed people over the course of time. We employ health satisfaction ("How satisfied are you with your health?") as the indicator for the state of health, which is measured on a Likert scale of 11. Health satisfaction was surveyed in all previous waves of the SOEP. We basically have access to information on the employment situation in Western Germany from 1984 until 2009 and in Eastern Germany from 1991 until 2009. In order to determine the contribution of the employment situation to explaining the change in health satisfaction, we use a decomposition method according to Blinder (1973) and Oaxaca (1973). Originally developed to analyse the gender-pay gap, decomposition methods can also be used to explain changes between two points in time (Schnabel/Wagner 2007). Although many speak of explanation in the context of decomposition, it is a purely descriptive method that allows for no secure causal conclusions.

On principle, the analysis should cover as long a period of time as possible. However, unlike the dependent variable "health satisfaction," the independent variables on the employment situation, which were of interest, were not always surveyed in each of the waves of the SOEP. The first survey wave of 1985 already provides us with complete information for Western Germany, so we can basically conduct a decomposition of the development from 1985 to 2009. However, we divide the analysis into two periods, from 1985 to 1996 and from 1996 to 2009. The year 1996 was chosen because it lies roughly at the middle of the period under observation and thus provides an impression of the course of time beyond the pure comparison of the time from 1985 to 2009. In addition, it is the first year for which all of the variables relevant for us are available for Eastern Germany at once. At the time of the analysis, the year 2009 was the most recent wave of the SOEP. ${ }^{4}$

The development of health over time is represented by the difference $\Delta$ of mean health satisfaction in the two years $\mathrm{t}=0$ (before) and $\mathrm{t}=1$ (after):

$$
\Delta_{t=1}^{t=0}=E\left(\mathrm{Sat}_{t=0}\right)-E\left(\mathrm{Sat}_{t=1}\right)
$$

Using the Blinder/Oaxaca decomposition, $\Delta_{t=1}^{t=0}$ can be broken down into two components. We first assume that the satisfaction with health in both periods is a linear function of the employment situation, represented by the vector $\mathrm{X}_{\mathrm{t}}^{\prime}$. The influ-

3 Since the Oaxaca-Blinder decomposition is based on cross-sectional analyses, we employ the corresponding cross-sectional weighting factors (DTC Version 8.0 - Desktop Companion to the German Socio-Economic Panel) for our analyses.

4 Usually, the sensitivity of the results with regard to the chosen comparison points can be tested by varying them slightly (e.g. instead of 2009, the year 2008). Unfortunately, this is not possible in this case, since then important variables would also be lacking in the analysis. However, if we look at the Figures 1 and 2 further below, it becomes apparent that the points in time observed by us either have a similar level as the times before and after them or are rather conservative (this means that the development over time does not have a great influence). 
ence of these variables on health is shown by the coefficient vector $\beta_{t}$. The subscript $t$ indicates that both, the variables and the coefficients, can be subject to a change over time. Under the assumption $E\left(\varepsilon_{t}\right)=0$ the following equation holds:

$$
E\left(\mathrm{Sat}_{t}\right)=E\left(X^{\prime}{ }_{t} \beta_{t}+\varepsilon_{t}\right)=E\left(X^{\prime}{ }_{t} \beta_{t}\right)=E\left(X^{\prime}{ }_{t}\right) \beta_{t} \quad t \in\{0,1\}
$$

Inserted in (1) then, after some transformations, we reach the following decomposition

$$
\Delta_{t=1}^{t=0}=\Delta_{w}+\Delta_{u}=\underbrace{\left[E\left(X_{t=0}\right)-E\left(X_{t=1}\right)\right]^{\prime} \beta_{t=0}}_{\text {explained }}+\underbrace{E\left(X_{t=1}\right)^{\prime}\left(\beta_{t=0}-\beta_{t=1}\right)}_{\text {unexplained }}
$$

In the literature, the first component $\Delta_{W}$ is often referred to as the "explained component." It is the percentage of the difference over time, that is due to the fact that the employment situation differs between the observed points in time (e.g. 1985 and 1996). $\Delta_{U}$, by contrast, is the percentage of the difference over time resulting from the different effect of one and the same employment situation over the course of time. In empirical analyses, however, $\Delta_{U}$ additionally includes those variables that are not represented in $\mathrm{X}_{\mathrm{t}}^{\prime}$, but which correlate with it and at the same time are relevant to health.

This leads to $\Delta_{U}$ not being distinctly attributable, and it is therefore often called the "unexplained component." In the following analysis we attempt to solve this problem by including various socio-demographic variables of the employees as control variables.

In addition to the aggregated decomposition, the coefficient effects and the structural effects can basically also be identified for each variable individually. However, this is only possible for the coefficient effects if all observed variables have an absolute zero, which is not the case in this analysis. If not from their relative explanatory importance, using a Wald test on the basis of a seemingly unrelated regression it is at least possible to get an impression of the change in the coefficients (cf. Tables 2 and A1). It has to be noted here that for categorical variables the results of the decomposition are dependent on the reference category; therefore we use the Stata ado oaxaca (Jann 2008) and the transformation implemented there (Jann 2008: 9-10).

Control variables were incorporated to take into account that there may be other reasons for a possible drop in the course of health satisfaction besides the changed employment situation. Age plays a role here in two ways. For one, due to the panel structure of the data the people automatically age. Secondly, also the labour participation of older people changes in the period under observation. The more distinct change in the labour participation of women is measured via a dummy variable for the sex of those surveyed, while another dummy variable also measures changes regarding the German nationality of the employed people. Finally, the level of education is included using the variable "years of education." The years of education are taken into consideration to illustrate structural effects of educational expansion 
on the composition of the employed people. Since we do not assume that there are differential effects of individual certificates, but that levels of education have a human capital effect on labour participation, we use years of education rather than dummies for each of the educational certificates. In this analysis, the levels of education of those surveyed are merely a control variable, so that for the sake of clarity we also do not need to include education dummies.

With regard to the employment situation, we aimed to cover as broad a spectrum as possible of the above structural changes. A number of variables serve to record a precarious employment situation. A dummy variable takes into account whether the observed people are in fixed-term jobs. We also record whether people work full or part-time or are in marginal employment. ${ }^{5}$ Since current developments such as temporary agency work, one-euro jobs, ${ }^{6}$ etc. could naturally only be taken into account in later waves, ${ }^{7}$ they could not be included in the time comparison conducted here. Instead, the subjective assessment of job security was used as an indicator for precarious (or perceived precarious) employment. In addition, a dummy variable was integrated in the model that records whether the current economy worries the person surveyed. The influence of exceedingly long working hours is recorded through the actual (not the contractual) working hours. The variable indicates by how many percent the actual working hours exceed those set down in the employment contract. Other factors are the accumulated duration of previous unemployment and the existence of relative poverty in spite of employment (measured by the equivalent household income). Poor in spite of employment is defined here as those whose household income is less than 60 percent of the average equivalent income (needs weighted according to the new OECD scale). The average incomes were calculated separately for East and West. We decided to use the household income rather than individual wages since the subject is poverty, which is usually measured in the household context (and not, for example, low wages, which can be supplemented by the income of partners). Further circumstances of employment are indicated using a dummy for employment in the public sector, changes with regard to the size of enterprises using the classified enterprise size and changes with regard to occupational autonomy action with an ordinal variable formed in the SOEP for this purpose. The geographical context can only be recorded very roughly, i.e. by taking into account the Länder (Federal States) of residence.

5 Translator's note: According to German social security law, marginal employment (geringfügige Beschäftigung, also called "mini-jobs" or "400-euro jobs") is an employment relationship with a low absolute level of earnings (slightly salaried employment), or employment relationship of short duration (short-term employment). In Germany such employment is exempt from social security.

6 One-euro jobs are job opportunities without social insurance contributions monitored by job centers for which unemployeds receive some additional payment (usually one or two euros per hour) onto their unemployment benefit.

7 E.g. job creation schemes starting in 1992 (with the exception of the year 1996) and temporary agency work starting in 2001. 
All in all, using the German Socio-Economic Panel Study we can map structural changes with a variety of variables. It must be taken into account that some of the indicators used here conceptually measure very similar aspects, e.g. subjective workplace security and fixed-term employment, or correlate empirically very highly with one another, e.g. years of education and previous duration of unemployment. This must be taken into consideration when interpreting the effects of the individual variables. However, their simultaneous use ensures a better measurement of the employment situation. This is unproblematic for interpreting the variables "en bloc" (Table 3), but when observing the explanatory power of individual variables (Table A2), this circumstance needs to be taken into account.

\section{$4 \quad$ Results}

As a starting point of the analysis, the SOEP data was used to examine whether a chronological trend regarding health could be ascertained. Then, in the first step, changes in the employment situation were identified in the observed years that may explain the potential changes in health. In the second step then we examined whether the impact of the employment situation on health was also subject to changes over time. Finally, in the third step the Blinder/Oaxaca decomposition was used to investigate what relative explanations both the changed employment situation and the changed impact of the employment situation had on health over the course of time.

\section{Health over the course of time}

Figures 1 and 2 show the extent to which a specific chronological development in health can be empirically observed, separately for Western and Eastern Germany. ${ }^{8}$ It must be noted here that these descriptive values have not been age adjusted (as otherwise is common in sociological health studies).

In Western Germany a drop in the trend of health satisfaction is observed among the employed between 20 and 65 years of age. While the average satisfaction was 7.2 points in 1984, in 2009 it was 6.8 points on the scale of satisfaction, which ranges from 0 to 10. As the confidence bands in Figure 1 indicate, this difference is statistically significant.

In Eastern Germany we also observe an initial declining trend in health satisfaction of the employed. However, this is entirely determined by the first two years of

8 The development of subjective health was also analysed with data from the different health surveys conducted by the Robert Koch Institute (RK/ 2009). The results of these analyses differentiated by East and West and according to three age groups show improvements in the subjective health assessment over the course of time, unlike the trend appearing here. Nonetheless, these results are not directly comparable with the results presented in this study, since the health surveys use a five-point scale to measure subjective health rather than an 11-point scale of health satisfaction and secondly because the ages were standardised through group classifications. 
Fig. 1: Change of health in Western Germany, 1984-2009

Scale value $[0 ; 10]$

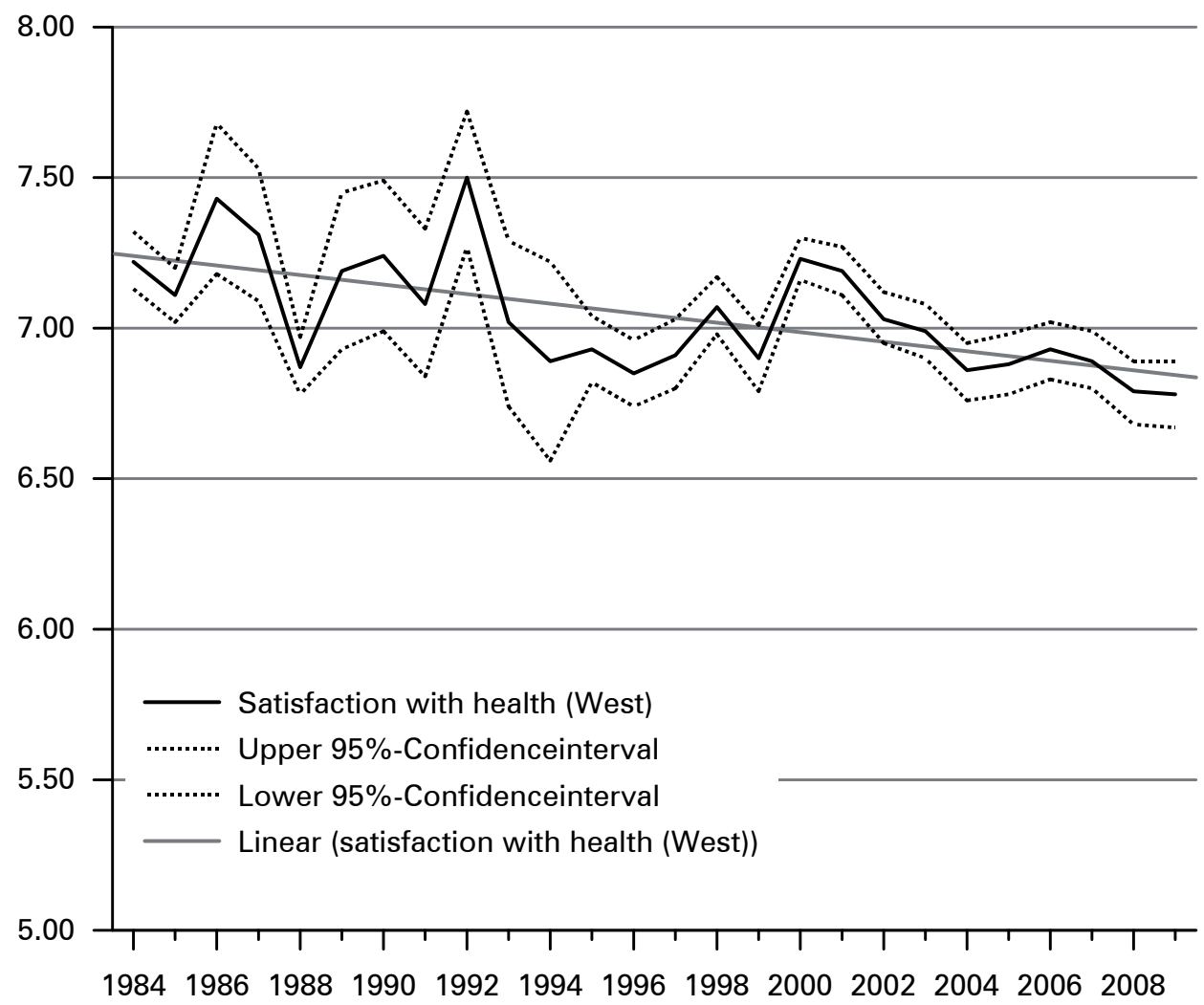

Source: own calculations, SOEP data

the survey 1991 and 1992. Then, from 1993 no significant change is observed in average health.

For both, Western and Eastern Germany, the description of the course of health satisfaction should not be over-interpreted due to the panel structure of the SOEP data. For example, the age demographic change among the employed may perhaps be overestimated, since the people who are surveyed repeatedly in the SOEP over the course of time naturally age and this tends to impair their state of health. The advantage of our use of the Blinder/Oaxaca decomposition below is that it removes the influence of a changed age composition (or other control variables) of those surveyed (cf. Table 3, the line "of which control variables"). However, this should be countered by the entry into employment of younger household members as well as partially through the weighting and the refresher samples. Since this analysis is not interested, however, in the influence of age composition itself on health satisfaction, it is sufficient to control for the age effect. Whether the changed age composition is 
Fig. 2: Change of health in Eastern Germany, 1991-2009

Scale value $[0 ; 10]$

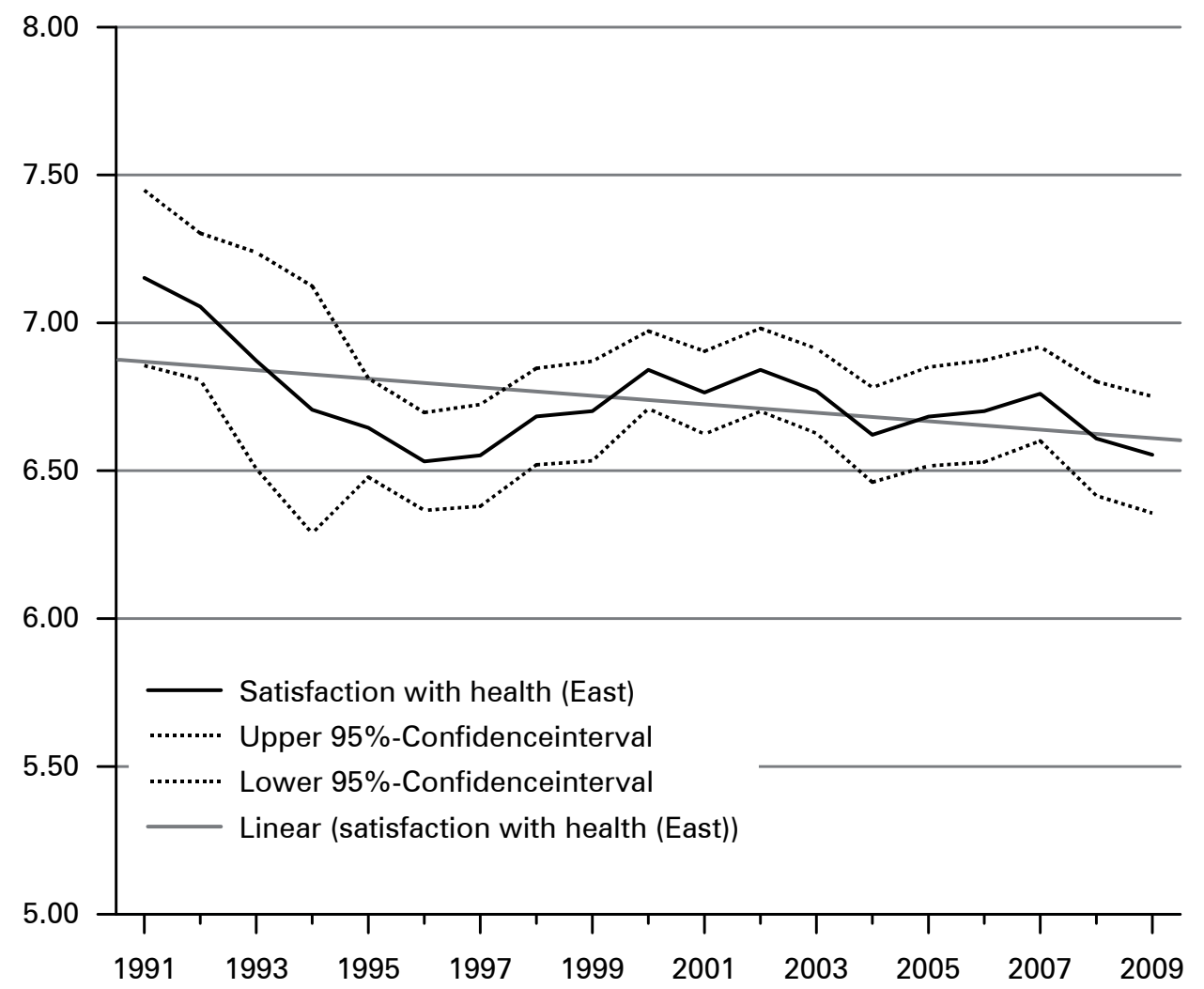

Source: own calculations, SOEP data

a consequence of the characteristics of the SOEP or of changed labour participation does not influence the results of the analysis.

As mentioned above, the state of research indicates two probable influencing mechanisms of the employment situation over the course of time on health. For one, the health of the employed can be influenced by a change in the employment situation that occurs over the course of time. Also, even an employment situation that remains constant can have different effects on health than it did earlier due to changed conditions on the labour market. An example of the first mechanism is when the number of precarious employment relationships increases over the course of time. An example of the second mechanism is when the negative influence of precarious employment on the state of health increases over the course of time. 


\section{Change in the employment situation}

Table 1 shows the changes of the average employment situation of those surveyed over the course of time. It contains the means for the control and structural variables we observed in each of the observed years. At first, we see the above-mentioned changes in the structure of the employed people with regard to their socio-demographic composition. Both for Eastern and Western Germany, the increased average age is clearly visible; in Western Germany from 39 years in 1985 to a little over 44 years in the year 2009 and similarly in Eastern Germany from almost 41 years in 1996 to over 44 years in 2009. As mentioned above, a part of this change can be due to the ageing of the sample. The increased labour participation of women in Western Germany in particular, but also in the East, is reflected. The percentage of non-German nationals among the employed drops from 25 percent to 6 percent, which could be due to both naturalisation processes as well as a higher risk of unemployment of foreigners. While for Western Germany the anticipated rise in years of education due to educational expansion is demonstrated, this number is, as anticipated, higher in Eastern Germany than in the West, but only rises slightly over the course of time. All in all, the results indicate that the relevant variables were necessary as control variables in the analysis.

If we look at changes in the employment situation of employees, changes in conditions on the labour market are reflected in the increased average accumulated duration of previous experience of unemployment. While the duration of previous unemployment in the employment biographies of Western German employees in the year 1985 was relatively low at approx. 2.9 months ( $=0.24$ years), by 1996 it rose to 4.8 months ( $=0.4$ years) and by 2009 to 5.6 months ( $=0.47$ years). In Eastern Germany, the rise of 3.8 months in the year 1996 to approx. 1 year (or 11.8 months) in 2009 is even more drastic. The percentage of employed people living in relative poverty measured on household income fluctuates in Western Germany at about 10 percent, and is at a lower level in Eastern Germany. ${ }^{9}$

The percentage of people employed in the public sector remains constant in the West at approx. 25 percent and drops considerably in Eastern Germany from an initial 34 percent to 29 percent. The enterprise size structures are also relatively constant, whereas here, too, the regions differ: In Western Germany a somewhat higher percentage of employed people work in large enterprises with over 2,000 employees, while in Eastern Germany higher percentages are employed by smaller enterprises (less than 200 employees).

The exceeding of contractually agreed working hours by the actual working hours rose in Western Germany from an initial average of 6 percent in the year 1985 to over 8 percent in the year 1996 to 9 percent in the year 2009. In Eastern Germany, the contractual working hours are exceeded on average by 11 percent. This value remains constant for the observed points in time.

9 Note that the average equivalent incomes on which the poverty rates are based are calculated separately for East and West and they are lower in the East. 
Tab. 1: Employment situation 1985, 1996 and 2009 in Western and Eastern Germany

\begin{tabular}{|c|c|c|c|c|c|c|c|c|c|c|}
\hline Control variables & \multicolumn{2}{|c|}{$\begin{array}{l}1985 \text { West } \\
\text { Mean } \\
\text { (standard } \\
\text { deviation) }\end{array}$} & \multicolumn{2}{|c|}{$\begin{array}{l}1996 \text { West } \\
\text { Mean } \\
\text { (standard } \\
\text { deviation) }\end{array}$} & \multicolumn{2}{|c|}{$\begin{array}{l}2009 \text { West } \\
\text { Mean } \\
\text { (standard } \\
\text { deviation) }\end{array}$} & \multicolumn{2}{|c|}{$\begin{array}{l}1996 \text { East } \\
\text { Mean } \\
\text { (standard } \\
\text { deviation) }\end{array}$} & \multicolumn{2}{|c|}{$\begin{array}{l}2009 \text { East } \\
\text { Mean } \\
\text { (standard } \\
\text { deviation) }\end{array}$} \\
\hline Age (years) & 39.13 & $(10.9)$ & 39.00 & $(0.7)$ & 44.10 & $(10.5)$ & 40.64 & $(9.8)$ & 44.20 & (10.5) \\
\hline Sex $(1$, if female $)$ & 0.35 & $(0.48)$ & 0.41 & $(0.49)$ & 0.48 & $(0.50)$ & 0.46 & $(0.50)$ & 0.51 & $(0.50)$ \\
\hline $\begin{array}{l}\text { Nationality: non-German } \\
\text { (1, if yes) }\end{array}$ & 0.25 & $(0.43)$ & 0.19 & $(0.40)$ & 0.06 & $(0.25)$ & - & $r^{-1}$ & - & - \\
\hline Years of education & 11.00 & $(2.45)$ & 11.52 & $(2.57)$ & 12.74 & (2.78) & 12.70 & (2.41) & 13.28 & (2.63) \\
\hline \multicolumn{11}{|l|}{$\begin{array}{l}\text { Structural variables } \\
\text { Previous experience with }\end{array}$} \\
\hline Relative poverty ( 1 , if yes) & 0.09 & (0.29) & 0.11 & $(0.32)$ & 0.08 & $(0.27)$ & 0.05 & $(0.22)$ & 0.07 & $(0.25)$ \\
\hline Public sector ( 1 , if yes) & 0.25 & $(0.43)$ & 0.24 & $(0.43)$ & 0.26 & $(0.44)$ & 0.34 & $(0.47)$ & 0.29 & $(0.45)$ \\
\hline $\begin{array}{l}\text { Enterprise size } \\
\text { Less than } 200\end{array}$ & \multicolumn{10}{|c|}{ Enterprise size } \\
\hline 200 to 2,000 employees & 0.47 & & 0.51 & $(0.50)$ & 0.54 & $(0.50)$ & 0.61 & $(0.49)$ & 0.61 & $(0.49)$ \\
\hline (dummy) & 0.25 & $(0.43)$ & 0.24 & $(0.43)$ & 0.22 & $(0.41)$ & 0.21 & $(0.41)$ & 0.20 & $(0.40)$ \\
\hline $\begin{array}{l}\text { More than 2,000 } \\
\text { employees (dummy) }\end{array}$ & 0.28 & $(0.45)$ & 0.25 & $(0.43)$ & 0.24 & $(0.43)$ & 0.18 & $(0.39)$ & 0.19 & $(0.40)$ \\
\hline \multicolumn{11}{|l|}{$\begin{array}{l}\text { Exceeding actual working } \\
\text { hours in \% over } \\
\text { contractual working }\end{array}$} \\
\hline hours & 0.06 & $(0.14)$ & 0.08 & $(0.13)$ & 0.09 & $(0.16)$ & 0.11 & $(0.16)$ & 0.11 & $(0.17)$ \\
\hline Job security (1, if no) & 0.44 & $(0.50)$ & 0.62 & $(0.48)$ & 0.59 & $(0.49)$ & 0.81 & $(0.39)$ & 0.75 & $(0.43)$ \\
\hline $\begin{array}{l}\text { Worried about economic } \\
\text { situation ( } 1 \text {, if yes) }\end{array}$ & 0.16 & $(0.37)$ & 0.16 & $(0.36)$ & 0.20 & $(0.40)$ & 0.23 & $(0.42)$ & 0.25 & $(0.43)$ \\
\hline \multicolumn{11}{|l|}{ Occupational autonomy } \\
\hline Very low (dummy) & 0.27 & $(0.45)$ & 0.22 & $(0.41)$ & 0.12 & $(0.33)$ & 0.11 & $(0.32)$ & 0.11 & $(0.32)$ \\
\hline Low (dummy) & 0.27 & $(0.45)$ & 0.28 & $(0.45)$ & 0.23 & $(0.42)$ & 0.35 & $(0.48)$ & 0.28 & (0.45) \\
\hline Medium (dummy) & 0.26 & $(0.44)$ & 0.28 & $(0.45)$ & 0.33 & $(0.47)$ & 0.29 & $(0.45)$ & 0.32 & $(0.46)$ \\
\hline High (dummy) & 0.16 & $(0.37)$ & 0.20 & $(0.40)$ & 0.25 & $(0.43)$ & 0.23 & $(0.42)$ & 0.25 & $(0.43)$ \\
\hline Very high (dummy) & 0.03 & $(0.17)$ & 0.03 & $(0.17)$ & 0.06 & $(0.24)$ & 0.02 & $(0.13)$ & 0.04 & (0.19) \\
\hline \multicolumn{11}{|l|}{ Employment status } \\
\hline Full-time (dummy) & 0.88 & $(0.33)$ & 0.82 & (0.39) & 0.72 & $(0.45)$ & 0.90 & $(0.30)$ & 0.79 & $(0.41)$ \\
\hline Part-time (dummy) & 0.11 & (0.31) & 0.15 & $(0.36)$ & 0.21 & $(0.41)$ & 0.09 & $(0.29)$ & 0.16 & $(0.37)$ \\
\hline $\begin{array}{l}\text { Marginal employment } \\
\text { (dummy)* }\end{array}$ & 0.01 & $(0.12)$ & 0.03 & $(0.16)$ & 0.07 & $(0.26)$ & 0.01 & $(0.09)$ & 0.05 & $(0.22)$ \\
\hline Fixed-term (1, if yes) & 0.05 & $(0.22)$ & 0.05 & $(0.22)$ & 0.07 & $(0.25)$ & 0.07 & $(0.26)$ & 0.10 & $(0.30)$ \\
\hline $\mathrm{N}$ & \multicolumn{2}{|c|}{2207} & \multicolumn{2}{|c|}{2059} & \multicolumn{2}{|c|}{3167} & \multicolumn{2}{|c|}{865} & \multicolumn{2}{|c|}{1098} \\
\hline
\end{tabular}

Note: In Eastern Germany, employees of non-German nationality were not included since the low cell numbers led to estimation problems in the regressions.

* Marginal employment is employment below a minimum salary (in 2013: 450 euros per month) with only flatrate social insurance contributions by employers and optional additional contributions by employee.

Source: own calculations, SOEP data 
One of the most striking developments, at least in Western Germany, is seen in subjective job security. The percentage of Western Germans who consider their job as insecure rose from 44 percent in the year 1985 to almost 60 percent in the year 2009. In Eastern Germany the amount is considerably higher, but dropped from 1996 to 2009 from about 80 percent to 75 percent. Similar observations can be seen when looking at those who are worried about the economy. In Eastern Germany the percentage of those who worry remains at a constant high level (approx. 25 percent), in Western Germany it rises form 16 to 20 percent. The development of occupational autonomy changes only slightly over the course of time. In Western Germany there is a slight shift towards high occupational autonomy and in Eastern Germany from low to medium autonomy. By contrast, the development in employment status is more distinct. Both in the East and West the percentage of full-time employees drops and the percentage of part-time employees as well as that of marginal employees rises constantly. Also, the percentage of the fixed-term employees rose constantly, if only slightly. In 2009 it was 7 percent in the West and 10 percent in the East of Germany.

Hence, for the first step of the analysis we can summarise that the above-described changes in the employment situation are also reflected to a great part in the data of the German Socio-Economic Panel Study. In the next section we will now look at the extent to which the significance of the employment situation has changed for health.

\section{Change in the correlations of employment situation and health}

Table 2 shows the linear ordinary least square (OLS) regression for health satisfaction on the control and structural variables for the years also included in the decomposition. Although the dependent variable "health satisfaction" is measured on an ordinal scale, the assumption made here of interval scaling for this type of variable is usually unproblematic (cf. e.g. Hamermesh 2001) and the variants of decomposition for non-linear regressions are often less robust with regard to omitted variables (cf. Krug et al. 2008: 13-14). However, it should be noted that the primary goal of the analyses is not to identify the coefficients of the individual variables. Therefore, the model also contains some variables - although not multicollinear that correlate highly in content. Nevertheless, by comparing the regression models we can read the extent to which the correlation with health of specific employment conditions, represented by the coefficients, changed over the course of time. Any two pairwise regressions were carried out as seemingly unrelated regressions. This ensures a more valid comparison of the coefficients when conducting the Wald tests (cf. Table A1 in the Appendix). For example, this can statistically test whether the coefficient of sex in the year $1985(-0.034)$ differs from the coefficients in 1996 $(0.105)$ - not merely seemingly, but also with statistical significance. ${ }^{10}$ However, the

10 As Table A1 shows, this is not the case; , the two coefficients are not statistically significantly different from one another, the $p$ value of the test is 0.53 . 
Tab. 2: Determinants of health, 1985, 1996 and 2009 in Western and Eastern Germany (OLS regression of health satisfaction)

\begin{tabular}{|c|c|c|c|c|c|}
\hline & $\begin{array}{c}1985 \text { West } \\
\text { Coefficients } \\
\text { (standard error) }\end{array}$ & $\begin{array}{c}1996 \text { West } \\
\text { Coefficients } \\
\text { (standard error) }\end{array}$ & $\begin{array}{c}2009 \text { West } \\
\text { Coefficients } \\
\text { (standard error) }\end{array}$ & $\begin{array}{c}1996 \text { East } \\
\text { Coefficients } \\
\text { ((standard error) }\end{array}$ & $\begin{array}{c}2009 \text { East } \\
\text { Coefficients } \\
\text { (standard error) }\end{array}$ \\
\hline \multicolumn{6}{|l|}{ Control variables } \\
\hline Age (years) & $\begin{array}{l}-0.046^{* * * *} \\
(0.005)\end{array}$ & $\begin{array}{l}-0.050^{* * * *} \\
(0.006)\end{array}$ & $\begin{array}{l}-0.040^{* * * *} \\
(0.005)\end{array}$ & $\begin{array}{l}-0.049 * * * * \\
(0.008)\end{array}$ & $\begin{array}{l}-0.038 * * * \\
(0.008)\end{array}$ \\
\hline Sex $(1$, if female $)$ & $\begin{array}{l}-0.034 \\
(0.132)\end{array}$ & $\begin{array}{r}0.105 \\
(0.143)\end{array}$ & $\begin{array}{r}0.067 \\
(0.127)\end{array}$ & $\begin{array}{r}-0.101 \\
(0.186)\end{array}$ & $\begin{array}{r}0.045 \\
(0.210)\end{array}$ \\
\hline Nationality: non-German ( 1 , if yes) & $\begin{array}{r}0.188 \\
(0.181)\end{array}$ & $\begin{array}{r}-0.081 \\
(0.213)\end{array}$ & $\begin{array}{l}0.506^{* *} \\
(0.227)\end{array}$ & - & $\begin{array}{l}- \\
-\end{array}$ \\
\hline Years of education & $\begin{array}{l}0.066^{* *} \\
(0.026)\end{array}$ & $\begin{array}{r}0.031 \\
(0.028)\end{array}$ & $\begin{array}{l}0.067^{* * *} \\
(0.025)\end{array}$ & $\begin{array}{r}0.041 \\
(0.039)\end{array}$ & $\begin{array}{r}-0.014 \\
(0.057)\end{array}$ \\
\hline \multicolumn{6}{|l|}{ Structural variables } \\
\hline $\begin{array}{l}\text { Previous experience with } \\
\text { unemployment (in years) }\end{array}$ & $\begin{array}{l}-0.111^{* *} \\
(0.053)\end{array}$ & $\begin{array}{l}-0.122^{* *} \\
(0.061)\end{array}$ & $\begin{array}{r}0.001 \\
(0.047)\end{array}$ & $\begin{array}{l}0.274^{*} \\
(0.142)\end{array}$ & $\begin{array}{l}-0.094^{* *} \\
(0.041)\end{array}$ \\
\hline Relative poverty (1, if yes) & $\begin{array}{r}-0.011 \\
(0.203)\end{array}$ & $\begin{array}{r}0.057 \\
(0.211)\end{array}$ & $\begin{array}{r}-0.336 \\
(0.239)\end{array}$ & $\begin{array}{r}0.315 \\
(0.329)\end{array}$ & $\begin{array}{r}0.380 \\
(0.313)\end{array}$ \\
\hline Public sector ( 1 , if yes) & $\begin{array}{r}0.135 \\
(0.125)\end{array}$ & $\begin{array}{r}-0.117 \\
(0.154)\end{array}$ & $\begin{array}{r}-0.190 \\
(0.132)\end{array}$ & $\begin{array}{r}0.190 \\
(0.177)\end{array}$ & $\begin{array}{r}-0.108 \\
(0.194)\end{array}$ \\
\hline \multicolumn{6}{|l|}{$\begin{array}{l}\text { Enterprise size (reference: less } \\
\text { than } 200 \text { employees) }\end{array}$} \\
\hline 200 to 2,000 employees & $\begin{array}{l}-0.068 \\
(0.131)\end{array}$ & $\begin{array}{r}0.042 \\
(0.149)\end{array}$ & $\begin{array}{l}-0.172 \\
(0.144)\end{array}$ & $\begin{array}{r}0.178 \\
(0.215)\end{array}$ & $\begin{array}{r}0.336 \\
(0.216)\end{array}$ \\
\hline More than 2,000 employees & $\begin{array}{r}-0.066 \\
(0.127)\end{array}$ & $\begin{array}{r}0.036 \\
(0.145)\end{array}$ & $\begin{array}{r}-0.006 \\
(0.127)\end{array}$ & $\begin{array}{l}-0.535^{* *} \\
(0.218)\end{array}$ & $\begin{array}{r}0.306 \\
(0.232)\end{array}$ \\
\hline Actual working hours & $\begin{array}{r}-0.203 \\
(0.422)\end{array}$ & $\begin{array}{r}0.297 \\
(0.402)\end{array}$ & $\begin{array}{l}-0.919^{* *} \\
(0.360)\end{array}$ & $\begin{array}{r}0.145 \\
(0.515)\end{array}$ & $\begin{array}{l}-1.538^{* * *} \\
(0.546)\end{array}$ \\
\hline Job security $(1$, if no) & $\begin{array}{r}-0.090 \\
(0.110)\end{array}$ & $\begin{array}{l}-0.355^{* * *} \\
(0.125)\end{array}$ & $\begin{array}{l}-0.694^{* * *} \\
(0.111)\end{array}$ & $\begin{array}{r}-0.015 \\
(0.177)\end{array}$ & $\begin{array}{l}-0.289 \\
(0.183)\end{array}$ \\
\hline $\begin{array}{l}\text { Worried about economic situation } \\
(1 \text {, if yes) }\end{array}$ & $\begin{array}{l}-0.445^{* * *} \\
(0.155)\end{array}$ & $\begin{array}{l}-0.718^{* * *} \\
(0.186)\end{array}$ & $\begin{array}{l}-0.578^{* * *} \\
(0.142)\end{array}$ & $\begin{array}{l}-0.778^{* * * *} \\
(0.203)\end{array}$ & $\begin{array}{l}-0.508^{* *} \\
(0.208)\end{array}$ \\
\hline \multicolumn{6}{|l|}{$\begin{array}{l}\text { Occupational autonomy } \\
\text { (reference: very low) }\end{array}$} \\
\hline Low & $\begin{array}{r}0.098 \\
(0.167)\end{array}$ & $\begin{array}{r}0.063 \\
(0.211)\end{array}$ & $\begin{array}{r}0.113 \\
(0.200)\end{array}$ & $\begin{array}{l}0.541^{*} \\
(0.311)\end{array}$ & $\begin{array}{l}-0.745^{* *} \\
(0.294)\end{array}$ \\
\hline Medium & $\begin{array}{r}0.055 \\
(0.173)\end{array}$ & $\begin{array}{r}0.094 \\
(0.211)\end{array}$ & $\begin{array}{r}0.263 \\
(0.195)\end{array}$ & $\begin{array}{l}0.630^{*} \\
(0.362)\end{array}$ & $\begin{array}{l}-0.545^{*} \\
(0.307)\end{array}$ \\
\hline High & $\begin{array}{r}-0.002 \\
(0.209)\end{array}$ & $\begin{array}{l}0.408^{*} \\
(0.228)\end{array}$ & $\begin{array}{r}0.250 \\
(0.236)\end{array}$ & $\begin{array}{r}0.425 \\
(0.339)\end{array}$ & $\begin{array}{r}0.097 \\
(0.399)\end{array}$ \\
\hline Very high & $\begin{array}{r}0.324 \\
(0.358)\end{array}$ & $\begin{array}{r}0.260 \\
(0.328)\end{array}$ & $\begin{array}{l}0.505^{*} \\
(0.284)\end{array}$ & $\begin{array}{r}0.350 \\
(0.905)\end{array}$ & $\begin{array}{r}-0.641 \\
(0.649)\end{array}$ \\
\hline \multicolumn{6}{|l|}{$\begin{array}{l}\text { Employment status (reference: } \\
\text { full-time) }\end{array}$} \\
\hline Part-time & $\begin{array}{r}0.004 \\
(0.192)\end{array}$ & $\begin{array}{r}0.191 \\
(0.177)\end{array}$ & $\begin{array}{r}-0.036 \\
(0.157)\end{array}$ & $\begin{array}{l}-0.694^{* *} \\
(0.352)\end{array}$ & $\begin{array}{r}0.204 \\
(0.293)\end{array}$ \\
\hline Marginal employment* & $\begin{array}{r}-0.125 \\
(0.379)\end{array}$ & $\begin{array}{r}0.138 \\
(0.415)\end{array}$ & $\begin{array}{l}-0.223 \\
(0.248)\end{array}$ & $\begin{array}{l}-1.448^{* * *} \\
(0.546)\end{array}$ & $\begin{array}{r}0.254 \\
(0.317)\end{array}$ \\
\hline $\begin{array}{l}\text { Fixed-term (reference: permanent } \\
\text { employment contract fixed-term) }\end{array}$ & $\begin{array}{r}0.052 \\
(0.232)\end{array}$ & $\begin{array}{l}-0.071 \\
(0.347)\end{array}$ & $\begin{array}{c}0.358^{*} \\
(0.195)\end{array}$ & $\begin{array}{r}0.187 \\
(0.344)\end{array}$ & $\begin{array}{r}0.401 \\
(0.287)\end{array}$ \\
\hline Constant & $\begin{array}{l}8.284^{* * * *} \\
(0.390)\end{array}$ & $\begin{array}{l}8.686^{* * * *} \\
(0.452)\end{array}$ & $\begin{array}{l}8.178^{* * * *} \\
(0.443)\end{array}$ & $\begin{array}{l}7.773^{* * *} \\
(0.659)\end{array}$ & $\begin{array}{l}9.191 * * * \\
(0.573)\end{array}$ \\
\hline $\mathrm{R}^{2}$ & $0.075^{* * *}$ & $0.103^{* * *}$ & $0.110^{* * *}$ & $0.138^{* * *}$ & $0.145^{* * *}$ \\
\hline $\mathrm{N}$ & 2207 & 2059 & 3167 & 865 & 1098 \\
\hline
\end{tabular}

Note: ${ }^{*} p<0.10,{ }^{*} p<0.05, * * * p<0.01$. In the regression estimations for Eastern Germany, employees of non-German nationality were not included since the low cell numbers led to estimation problems.

* Marginal employment is employment below a minimum salary (in 2013: 450 euros per month) with only flatrate social insurance contributions by employers and optional additional contributions by employee.

Source: own calculations, SOEP data 
procedure apparently leads to rather conservative tests, i.e. to rather high $\mathrm{p}$ values, which must be taken into consideration when interpreting the results. We therefore also consider variables where the $p$ value somewhat exceeds the limit of 0.1.

Beginning with Western Germany, it is striking that the regression results for the years 1985 and 1996 are quite similar, which means that the effect of the employment situation does not change much over the years. In a Wald test for the equality of the models, the null hypothesis is not rejected with a $p$ value of 0.85 . As for the individual coefficients, here, too, there are no significant differences. With $p$ values around 0.13 in the Wald tests, however, the change in the variable of job security is notable. Hence, it seems that the impact of subjective job insecurity has changed over the course of time, from a slightly negative insignificant effect in 1985 to a considerably negative and significant effect on health in 1996. This suggests that a negative effect of a precarious employment situation on health does not arise per se, but only developed over the course of time. The impact of employment in the public sector also changed ( $p$ value of 0.21 ). While at first positive, it develops in a negative direction, although the two coefficients are not significant.

For the comparison of the whole 1996 and 2009 regression models there is also no statistically significant difference, however, at 0.11 the $p$ value is remarkably low. Correspondingly, individual coefficients also show significant differences. First of all, the distinctly positive effect of non-German nationality in the year $2009 \mathrm{com}$ pared with 1996 is of interest. One explanation for this could be that at the two points in time different groups of foreigners are aggregated under the dummy "nonGerman nationality." Conversely, in 2009 there is a distinct and negative effect of additional working hours, which did not yet exist as such in 1996. But the negative impact of a lack of job security also intensified ( $p$-value for comparison of the coefficients in 1996 and 2009: 0.03).

The 1996 and 2009 regression models for Eastern Germany show more distinct differences than for Western Germany and these differences are statistically highly significant with a $p$ value of 0.002 . With regard to the individual variables there are significant differences in the impact of occupational autonomy and enterprise size. It is interesting that the negative effect of part-time work and marginal employment observed in 1996 is positive in the year 2009, although not significantly. ${ }^{11}$

\section{Relative explanatory importance of changed employment conditions for the decline in health over the course of time}

In the third and final step, we now present the results of the Blinder/Oaxaca decomposition, which indicates the relative explanatory importance of the changes presented in Tables 1 and 2. Table 3 summarises the results, while Table A2 in the Appendix shows the relative explanatory importance differentiated for all observed control variables and indicators of structural change.

11 This rather counterintuitive development is related to the above-mentioned correlation of the variables. 
Tab. 3: Blinder/Oaxaca decomposition of health satisfaction (0-10 points), 1985/1996 and 1996/2009, in Western and Eastern Germany

\begin{tabular}{|c|c|c|c|c|c|c|}
\hline & \multicolumn{2}{|c|}{ 1985/1996 West } & \multicolumn{2}{|c|}{ 1996/2009 West } & \multicolumn{2}{|c|}{ 1996/2009 East } \\
\hline \multirow[t]{2}{*}{ Mean before } & $7.126^{* * *}$ & & $6.902 * * *$ & & $6.553^{* * *}$ & \\
\hline & $(0.053)$ & & $(0.062)$ & & $(0.084)$ & \\
\hline \multirow[t]{2}{*}{ Mean after } & $6.902 * * *$ & & $6.820 * * *$ & & $6.618^{* * *}$ & \\
\hline & $(0.062)$ & & $(0.058)$ & & $(0.100)$ & \\
\hline \multirow[t]{2}{*}{ Difference } & $-0.224 * * *$ & & -0.082 & & 0.065 & \\
\hline & $(0.077)$ & & $(0.083)$ & & $(0.128)$ & \\
\hline $\begin{array}{l}\text { Decomposition of the } \\
\text { difference }\end{array}$ & Absolute & $\%$ & Absolute & $\%$ & absolute & $\%$ \\
\hline \multirow[t]{2}{*}{ Total } & $-0.098 * *$ & 44 & $-0.095^{* *}$ & 116 & -0.084 & -129 \\
\hline & $(0.038)$ & & $(0.040)$ & & $(0.068)$ & \\
\hline \multirow{2}{*}{$\begin{array}{l}\text { of which control } \\
\text { variables }\end{array}$} & $-0.047^{*}$ & 21 & -0.024 & 29 & $-0.066 * *$ & -102 \\
\hline & $(0.026)$ & & $(0.033)$ & & $(0.033)$ & \\
\hline \multirow{2}{*}{$\begin{array}{l}\text { of which structural } \\
\text { effects }\end{array}$} & -0.050 & 22 & $-0.070 * *$ & 85 & -0.018 & -28 \\
\hline & $(0.031)$ & & $(0.030)$ & & $(0.061)$ & \\
\hline \multirow{2}{*}{$\begin{array}{l}\text { Unexplained } \\
\text { (coefficient effects) }\end{array}$} & -0.126 & 56 & 0.013 & -16 & 0.149 & 229 \\
\hline & $(0.081)$ & & $(0.084)$ & & $(0.126)$ & \\
\hline Number of cases & 4266 & & 5226 & & 1963 & \\
\hline
\end{tabular}

Note: ${ }^{*} p<0.10,{ }^{*} p<0.05,{ }^{* * *} p<0.01$; robust standard errors in brackets, Percentages do not sum up to 100 percent due to rounding errors

Example calculation:

$\Delta_{t=2009}^{t=1996}=\Delta_{w}+\Delta_{u}=-0.082=-0.095+0.013=-0.024-0.070+0.013$

Source: own calculations, SOEP data

Let us first look at the development in Western Germany. There, satisfaction with health in the first time interval from 1985 until 1996 dropped from an average 7.126 to 6.902 points. This corresponds to a decline by approx. 0.224. The Blinder/Oaxaca decomposition shows that with 0.126 points roughly 56 percent of this lessened health satisfaction correlates with a changed impact of employment conditions on health (or with unobserved variables). By contrast, 0.098 points or 44 percent of the decline is caused by the composition of the employed people. If we account for the influence of the control variables (age, education, etc.), then only 0.050 points or 22 percent remain that are explainable by changes in the employment situation itself.

At first the second time interval, from 1996 until 2009, appears similar; the downward trend continues and health satisfaction drops from 6.902 points by another 0.082 points to 6.820 points. The decomposition reveals, however, that the condi- 
tions of the changes have altered. During the second time interval merely a negligibly small part is explained by the coefficient effects and the unobserved variables. With 0.013 points or -16 percent, unobserved changes have a slightly positive influence on satisfaction with health. This is, however, canceled out by the far greater changes in the composition of the employed people and the employment situation. Yet, the control variables lose explanatory power with -0.024 or 29 percent compared with the previous period, mainly due to the fact that the negative effect of aging is balanced out by a positive effect of the higher levels of education (cf. Table A2). If we exclude the influence of the control variables, then structural changes still explain 0.070 points or 85 percent of the negative change in health satisfaction.

If we now turn to Eastern Germany, we notice that in the observation interval from 1996 until 2009 a slight improvement in health occurred. However, the decomposition reveals that also in Eastern Germany, due to changes in the sociodemographic control variables, primarily age, a decline in health satisfaction would have occurred. Changes in the employment situation, by contrast, have hardly any influence or the negative influence is eliminated by a number of changes in the employment situation with positive effects on health, as is the case with an increased percentage of the population with long experiences with unemployment (cf. Table A2). The decline that is due to the changed age composition is now balanced out by coefficient effects or unobserved changes, which then leads ultimately to an improvement in health. The available data cannot explain what development is responsible for this.

\section{$5 \quad$ Summary and Discussion}

In this article, we investigated the question of whether the structural changes in gainful employment documented in labour market and occupational sociology, which can be described as an increasing precarisation of employment, have a diminishing effect on subjective health satisfaction or whether it is developing positively, similar to the long-term trend in life expectancy. Many of the mechanisms that explain the social gradient of health outcomes can ultimately be linked to the employment situation and its material and immaterial resources and stress.

Using data from the German Socio-Economic Panel Study (SOEP), we first examined how the subjective health satisfaction of employed people has developed over the past two decades in Germany. It is common in socio-epidemiological studies to carry out age standardisation when examining chronological trends. Such standardisation was not done in this case because a changed demographic composition of personnel can have impacts on organisations, such as requirements for age-based design of workplaces, which would be masked by standardisation. Age standardised analyses of the SOEP in the context of the Federal government's Health Report (Gesundheitsberichterstattung des Bundes 2006) reveal relatively constant values in the subjective health satisfaction for the average of all population groups, while our descriptive values show a constant to slightly rising satisfaction among employed people in Eastern Germany, but declining values in Western Germany. In the second 
step, we looked at the effect of structural variables of the employment situation and other demographic control variables on subjective health in the cross section of the years 1985, 1996 and 2009 selected due to the data situation (in Eastern Germany only for the last time interval), in order to check whether the employment situation is of actual significance. We moreover aimed to investigate what particular effects changed their significance over the course of time.

Why could this be the case? We try to illustrate this social mechanism using the example of subjective employment security. Contextual effects could play a role here. During a period characterised by low unemployment rates the insecurity of one's own employment relationship need not necessarily cause stress. If there is high demand for workers, one has a good chance of quickly finding another job. In a situation dominated by high unemployment, job insecurity will presumably be subjectively perceived as more stressful. Of course, how well the social safety net functions in the case of unemployment also plays a role. The better the coverage the less stressful job insecurity may be.

In the third step of our analysis, we carried out a Blinder/Oaxaca decomposition to clarify whether the structural changes on the labour market or the development of control and unobserved variables could be deemed responsible for the change in subjective health. The advantage of this method is that we can differentiate the extent to which changes can be explained by the altered socio-demographic composition of the employed or by the changed number of people in work situations that are potentially harmful to health. We can also differentiate what percentage of a change over time is due to a changed effect of these influencing factors (sociodemographic variables and work situation).

Using the SOEP data for employed people in Germany, from 1985 until 2009 there is a significantly declining health satisfaction for Western Germany, and for Eastern Germany from 1996 until 2009 a positive, but statistically insignificant change in health satisfaction. If we exclude the influence of a change in the composition of employed people with regard to age, levels of education, sex and nationality, all in all on the macro level for Eastern and for Western Germany, there are hardly any greater correlations between declining health and the changed employment situation. ${ }^{12}$ It does, however, become apparent for Western Germany that a significant share of the decline in health satisfaction since 1985 can be explained by the rising numbers of employees in insecure employment relationships or with concerns about the economy. As the analyses in Tables 2 and Table A1 show, not only the percentage of those affected by this has risen, but also their negative impact on (or the negative correlation with) health, at least with regard to job security. While in 1985 there was hardly any correlation between job security and health, in 1996 it was distinctly negative and then almost doubled between 1996 and 2009. In addition,

12 This does not, however, mean that such correlations do not exist at the individual level. At the individual level, "poverty in spite of employment" can nonetheless have negative effects on health satisfaction, even if the number of people living in poverty in spite of being in employment has no explanatory significance for a changed average health of the entire employed population. 
it is apparent that the increased number of employed people who assess their job situation as insecure or who worry about economic developments have significant and substantial explanatory importance for the decline in health satisfaction over the course of time. In Eastern Germany, by contrast, we observe neither relative explanatory importance related to this insecurity nor a decline in health satisfaction. Nonetheless the level of job insecurity and the number of employed people who worry is far higher than in Western Germany.

Nevertheless, using the available data it is not possible to finally clarify whether increased insecurity leads to a decline in health or, conversely, whether a decline in health results in employed people worrying more about their jobs and the economy. Yet, based on the changes in employment situations described earlier it appears quite plausible that the growing employment insecurity linked with this change has a causal and negative effect on health.

All in all, the changes examined in subjective health satisfaction are not very grave. Therefore, it would be interesting for future studies to examine how major cuts in the labour market, for example through far-reaching transformation processes, affect subjective health satisfaction. Unfortunately, such situations can rarely be documented in a suitable data basis. The German Socio-Economic Panel Study, which actually provides relatively differentiated information on the employment situation, also offers only a few waves in which all of the variables needed for our question were surveyed simultaneously. It would also be intriguing to study this issue in an international comparison in countries with differing labour market situations and differing levels of prosperity, in order to ascertain how the individual employment situation correlates with subjective health satisfaction in the context of the respective reference systems.

Future studies could use the Oaxaca/Blinder decomposition to investigate the changing influences of other factors such as familial situations. Originally developed for the purpose of decomposing the gender-pay gap, this method is a helpful instrument for the analysis of longterm structural changes.

\section{References}

Benach, Joan; Muntaner, Carles; Santana, Vilma 2007: Employment conditions and health inequalities. Final report to the WHO Commission on social determinants of health (CSDH) [URL: http://www.who.int/social_determinants/resources/articles/emconet_who_report.pdf, 08.07.2012].

Blinder, Alan S. 1973: Wage discrimination: reduced form and structural variables. In: Journal of Human Resources 8,4: 436-455.

Böckerman, Petri; Ilmakunnas, Pekka 2009: Unemployment and self-assessed health. Evidence from panel data. In: Health Economics 18,2: 161-206 [doi: 10.1002/hec.1361].

Bohle, Philip; Quinlan, Michael; Kennedy, David; Williamson, Ann 2004: Working hours, work life conflict and health in precarious and 'permanent' employment. In: Revista de Saúde Pública 38: 19-25 [doi: 10.1590/S0034-89102004000700004]. 
Borrell, Carme; Muntaner, Carles; Benach, Joan; Artazcoza, Lucia 2004: Social class and self-reported health status among men and women: what is the role of work organisation, household material standards and household labour? In: Social Science \& Medicine 58,10: 1869-1887.

Brehmer, Wolfram; Seifert, Hartmut 2008: Sind atypische Beschäftigungsverhältnisse prekär? Eine empirische Analyse sozialer Risiken. In: Zeitschrift für Arbeitsmarktforschung 4: 501-531.

Browning, Martin; Møller Danø, Anne; Heinesen, Eskil 2006: Job displacement and stress related health outcomes. In: Health Economics 15: 1061-1075 [doi: 10.1002/ hec.1101].

Burgard, Sarah A.; Brand, Jennie E.; House, James S. 2007: Toward a better Estimation of the effect of job loss on health. In: Journal of Health and Social Behavior 48: 369-384 [doi: 10.1177/002214650704800403].

DTC Desktop Companion to the German Socio-Economic Panel (SOEP) 2005: Edited by John P. Haisken-DeNew, Joachim R. Frick, Version 8.0 - Dec 2005 Updated to Wave 21 (U). [URL: http://www.diw.de/de/diw_02.c.222846.de/handbuch_dtc.html\#236958 retrieved on 08.08.2012]

Dinkel, Reiner H. 2002: Die langfristige Entwicklung der Sterblichkeit in Deutschland. In: Zeitschrift für Gerontologie und Geriatrie 35,5: 400-405 [doi: 10.1007/ s00391-002-0120-7].

Dragano, Nico 2007: Arbeit, Stress und krankheitsbedingte Frührenten: Zusammenhänge aus theoretischer und empirischer Sicht. Wiesbaden: VS Verlag.

Dragano, Nico; Siegrist, Johannes 2012: The relationship between downsizing, psychosocial stress at work and health. In: Kieselbach, Thomas; Mannila, Simo (Eds.): Unemployment, precarious work and health. Research and policy issues. Wiesbaden: VS Verlag: 277-286.

Dragano, Nico; Verde, Pablo Emilio; Siegrist, Johannes 2005: Organisational downsizing and work stress: testing synergistic health effects in employed men and women. In: Journal of Epidemiology and Community Health 59: 694-699 [doi: 10.1136/ jech.2005.035089].

Eichhorst, Werner; Kuhn, Andrea; Thode, Eric; Zenker, Rosemarie 2010: Traditionelle Beschäftigungsverhältnisse im Wandel. IZA Research Report No. 23. Bonn: IZA.

Ferraro, Kenneth F.; Farmer, Melissa M. 1999: Utility of health data from social surveys: Is there a gold standard for measuring morbidity? In: American Sociological Review 64,2: 303-315.

Gesundheitsberichterstattung des Bundes 2006: Gesundheit in Deutschland. RobertKoch-Institut, Statistisches Bundesamt. Berlin [http://www.gbe-bund.de/gbe10/ owards.prc_show_pdf?p_id=9965\&p_sprache=D, 08.08.2012].

Giesecke, Johannes 2006: Arbeitsmarktflexibilisierung und Soziale Ungleichheit. Sozioökonomische Konsequenzen befristeter Beschäftigungsverhältnisse in Deutschland und Großbritannien. Diss. Wiesbaden: VS Verlag.

Gundert, Stefanie; Hohendanner, Christian 2011: Leiharbeit und befristete Beschäftigung. Soziale Teilhabe ist eine Frage von stabilen Jobs. IAB Kurzbericht 4/2011. Nürnberg: IAB.

Hamermesh, Danie/ S. 2001: The Changing Distribution of Job Satisfaction. In: The Journal of Human Resources 36,1: 1-30 [doi: 10.2307/3069668]. 
Helmert, Uwe; Schorb, Friedrich 2009: Die Bedeutung verhaltensbezogener Faktoren im Kontext der sozialen Ungleichheit der Gesundheit. In: Richter, Matthias; Hurre/mann, Klaus (Eds.): Gesundheitliche Ungleichheit: Grundlagen, Probleme, Perspektiven. Wiesbaden: VS Verlag: 125-139.

Hoffmann, Edeltraud; Walwei, Ulrich 1998: Normalarbeitsverhältnis: ein Auslaufmodell? Überlegungen zu einem Erklärungsmodell für den Wandel der Beschäftigungsformen. In: Mitteilungen aus der Arbeitsmarkt- und Berufsforschung 31: 409-425.

Hohendanner, Christian 2010: Befristete Arbeitsverträge zwischen Auf- und Abschwung. Unsichere Zeiten, unsichere Verträge? IAB Kurzbericht 14/2010. Nürnberg: IAB.

Hollederer, Alfons 2008: Psychische Gesundheit im Fall von Arbeitslosigkeit. In: Praktische Arbeitsmedizin 12,10: 29-32.

Hollederer, Alfons 2011: Erwerbslosigkeit, Gesundheit und Präventionspotenziale. Ergebnisse des Mikrozensus 2005. Habilitationsschrift. Wiesbaden: VS Verlag.

Hyman, Jeff; Baldry, Chris; Scholaris, Dora; Bunzel, Dirk 2003: Work-life imbalance in call centres and software development. In: British Journal of Industrial Relations 41,2: 215-139 [doi: 10.1111/1467-8543.00270].

Idler, Ellen L.; Benyamini, Yae/ 1997: Self-rated health and mortality: A review of twentyseven community studies. In: Journal of Health and Social Behavior 38,1: 21-37.

Jahn, Elke; Rudolph, Helmut 2002: Zeitarbeit - Teil II. Völlig frei bis streng geregelt: Variantenvielfalt in Europa. IAB-Kurzbericht 21/2002. Nürnberg: IAB.

Jann, Ben 2008: The Blinder-Oaxaca decomposition for linear regression models. In: Stata Journal 8,4: 453-479 [http://www.stata-journal.com/article.html?article=st0151, 08.08.2012].

Janßen, Christian; Heinrich, Cordula; Chrispin, Alexander; Weitkunat, Rolf; Abel, Thomas 2000: Sozio-ökonomischer Status und gesundheitliche Kontrollüberzeugungen. In: Zeitschrift für Gesundheitswissenschaft 8,3: 216-229 [doi: 10.1007/BF02962612].

Johansson, Gunn; Johnson, Jeffrey V.; Hall, Ellen M. 1991: Smoking and sedentary behavior as related to work organization. In: Social Science \& Medicine 32,7: 837-846 [doi: 10.1016/0277-9536(91)90310-9].

Jungbauer-Gans, Monika 2002: Ungleichheit, soziale Beziehungen und Gesundheit. Habilitationsschrift. Wiesbaden: Westdeutscher Verlag.

Jungbauer-Gans, Monika; Kriwy, Peter 2003: Der Arzteinfluss auf die Durchimpfungsrate. In: Das Gesundheitswesen 65: 464-470 [doi: 10.1055/s-2003-40806].

Karasek, Robert A. 1979: Job demands, job decisions latitude, and mental strain: implications for job redesign. In: Administrative Science Quarterly 24,2: 285-307.

Karasek, Robert A.; Theorell, Töres 1990: Healthy work. New York: Basic Books.

Kieselbach, Thomas; Mannila, Simo (Eds.) 2012: Unemployment, precarious work and health. Research and policy issues. Wiesbaden: VS Verlag.

Klein, Thomas 2001: Der Einfluss differentieller Mortalität auf den ökonomischen Status im Alter In: Becker, Irene; Ott, Notburga; Rolf, Gabriele (Eds.): Soziale Sicherung in einer dynamischen Gesellschaft. Frankfurt: Campus: 486-502.

Kock, Klaus 2008: Auf Umwegen in den Beruf. Destandardisierte und prekäre Beschäftigung von Jugendlichen an der zweiten Schwelle - eine Auswertung empirischer Befunde. Sozialforschungsstelle Dortmund. Beiträge aus der Forschung Bd. 162. HansBöckler-Stiftung Projekt-Nr. 2007-006-3. Dortmund. 
Kroll, Lars Eric 2010: Sozialer Wandel, soziale Ungleichheit und Gesundheit. Die Entwicklung sozialer und gesundheitlicher Ungleichheiten in Deutschland zwischen 1984 und 2006. Wiesbaden: VS Verlag.

Krug, Gerhard; Dietz, Martin; Ullrich, Britta 2008: The impact of firm characteristics on the success of employment subsidies. A decomposition analysis of treatment effects. IAB Discussion Paper 18/2008. Nürnberg: IAB.

Lahelma, Eero 2006: Health inequalities - the need for explanation and intervention. In: European Journal of Public Health 16: 339 [doi: 10.1093/eurpub/ckl106].

Lampert, Thomas 2011: Armut und Gesundheit. In: Schott, Thomas; Hornberg, Claudia (Eds.): Die Gesellschaft und ihre Gesundheit. 20 Jahre Public Health in Deutschland: Bilanz und Ausblick einer Wissenschaft. Wiesbaden: VS Verlag: 575-597.

Lampert, Thomas; Saß, Anke-Christine; Häfelinger, Michael; Ziese, Thomas 2005: Armut, soziale Ungleichheit und Gesundheit. Expertise des Robert Koch-Instituts zum 2. Armuts- und Reichtumsbericht der Bundesregierung. Berlin: Robert Koch-Institut [http://edoc.rki.de/documents/rki_fv/reJBwqKp45Pil/PDF/24aj8tYVir1Lo_14.pdf, 08.08.2012].

Leopold, Liliya; Engelhardt, Henriette 2011: Bildung und Gesundheitsungleichheit im Alter: Divergenz, Konvergenz oder Kontinuität? Eine Längsschnittuntersuchung mit SHARE. In: Kölner Zeitschrift für Soziologie und Sozialpsychologie 63: 207-236 [doi: 10.1007/s11577-011-0133-6].

Maaz, Asja; Winter, Maik Hans-Joachim; Kuhlmey, Adelheid 2007: Der Wandel des Krankheitsparadigmas und die Bedeutung chronischer Krankheiten (Epidemiologie, Kosten). In: Badura, Bernhard; Schellschmidt, Henner; Vetter, Christian (Eds.): Fehlzeiten-Report 2006. Zahlen, Daten, Analysen aus allen Branchen der Wirtschaft. Chronische Krankheiten. Betriebliche Strategien zur Gesundheitsförderung, Prävention und Wiedereingliederung. Berlin: Springer: 5-22.

Mackenbach, Johan P. 2006: Health inequalities: Europe in profile. An independent expert report commissioned by the UK presidency of the EU. London: Department of Health.

Mannila, Simo 2012: Informal labour and health effects: Introducing a research problem. In: Kieselbach, Thomas; Mannila, Simo (Eds.): Unemployment, precarious work and health. Research and policy issues. Wiesbaden: VS Verlag: 173-180.

Nocon, Marc; Keil, Thomas; Willich, Stefan N. 2007: Education, income, occupational status and health risk behavior. In: Journal of Public Health 15: 401-405 [doi: 10.1007/ s10389-007-0120-6].

Nolte, Ellen; McKee, Martin 2004: Changing health inequalities in east and west Germany since unification. Social Science and Medicine 58,1: 119-136. [doi: 10.1016/ S0277-9536(03)00153-9].

Oaxaca, Ronald 1973: Male-female wage differentials in urban labor markets. In: International Economic Review 14,3: 693-709.

O'Campo, Particia; Eaton, William W.; Muntaner, Carles 2004: Labor market experience, work organization, gender inequalities and health status: results from a prospective analysis of US employed women. In: Social Science \& Medicine 58,3: 585-594.

Oppolzer, Alfred 2010: Psychische Belastungsrisiken aus Sicht der Arbeitswissenschaft und Ansätze für die Prävention. In: Badura, Bernhard; Schröder, Helmut; Klose, Joachim; Macco, Katrin (Eds.): Fehlzeiten-Report 2009. Arbeit und Psyche: Belastungen reduzieren - Wohlbefinden fördern. Teil A, Part 1, 13-22. Heidelberg: Springer [doi: 10.1007/978-3-642-01078-1_2]. 
Otsuka, Yasumasa; Yamate, Yuko; Kosugi, Shotaro 2012: Organisational downsizing and psychosocial work characteristics: A longitudinal study of Japanese white-collar workers. In: Kieselbach, Thomas; Mannila, Simo (Eds.): Unemployment, precarious work and health. Research and policy issues. Wiesbaden: VS Verlag: 287-296.

Peter, Richard 2006: Psychosoziale Belastungen im Erwachsenenalter. Ein Ansatz zur Erklärung sozialer Ungleichverteilung von Gesundheit? In: Richter, Matthias; Hurre/mann, Klaus (Eds.): Gesundheitliche Ungleichheit. Grundlagen, Probleme, Perspektiven. Wiesbaden: VS Verlag: 109-124.

Reibling, Nadine; Wendt, Claus 2010: Bildungsniveau und Zugang zu Gesundheitsleistungen. Eine vergleichende Analyse von Zugangsregulierung und Inanspruchnahme fachärztlicher Leistungen in Europa. In: Das Gesundheitswesen 72: 447-454 [doi: 10.1055/s-0029-1234101].

RKI 2009: 20 Jahre nach dem Fall der Mauer: Wie hat sich die Gesundheit in Deutschland entwickelt. Beiträge zur Gesundheitsberichterstattung des Bundes. Berlin: Robert Koch-Institut [http://www.gbe-bund.de/gbe10/owards.prc_show_pdf?p_id=12449\&p_ sprache $=$ d\&p_uid=gastg\&p_aid=17639826\&p_Ifd_nr=1, 08.08.2012].

Richter, Matthias; Hurrelmann, Klaus 2006: Gesundheitliche Ungleichheit. Ausgangsfragen und Herausforderungen. In: Richter, Matthias; Hurrelmann, Klaus (Eds.): Gesundheitliche Ungleichheit: Grundlagen, Probleme, Perspektiven. Wiesbaden: VS Verlag: 11-32.

Salm, Martin 2009: Does unemployment cause ill health? In: IZA Discussion Paper No. 4147. Bonn: IZA.

Schmitz, Hendrik 2010: Why are the unemployed in worse health? The causal effect of unemployment on health. In: Labour Economics 18,1: 71-78 [doi: 10.1016/j. labeco.2010.08.005].

Schnabel, Claus; Wagner, Joachim 2007: The persistent decline in unionization in Western and Eastern Germany, 1980-2004: What can we learn from a decompositions analysis? In: Industrielle Beziehungen 14,2: 118-132. [doi: 10.1688/1862-0035 indb_2007_02_schnabel_wagner].

Siegrist, Johannes 1989: Steps towards explaining social differentials in morbidity: The case of West Germany. In: Fox, John (Eds.): Health inequalities in European countries. Eldershot: Gower: 353-371.

Siegrist, Johannes 1996: Adverse health effects of high-effort/low-reward conditions. In: Journal of Occupational Health Psychology 1,1: 27-41 [doi: 10.1037/1076-8998.1.1.27].

Siegrist, Johannes; Dragano, Nico 2008: Psychosoziale Belastungen und Erkrankungsrisiken im Erwerbsleben. Befunde aus internationalen Studien zum AnforderungsKontroll-Modell und zum Modell beruflicher Gratifikationskrisen. In: Bundesgesundheitsblatt - Gesundheitsforschung - Gesundheitsschutz 51,3: 305-312 [doi: 10.1007/ s00103-008-0461-5].

Siegrist, Johannes; Siegrist, Karin; Weber, Ingbert 1986: Sociological concepts in the etiology of chronic disease: the case of ischemic heart disease. In: Social Science \& Medicine 22: 247-253 [doi: 10.1016/0277-9536(86)90073-0].

Siegrist, Johannes; Theorell, Töres 2006: Socio-economic position and health. The role of work and employment. In: Siegrist, Johannes; Marmot, Michael (Eds.): Social inequalities in health. New evidence and policy implications. Oxford: University Press: 73-100. 
Siegrist, Johannes; Dragano, Nico; Wahrendorf, Morton 2009: Psychosoziale Arbeitsbelastungen und Gesundheit bei älteren Erwerbstätigen: eine europäische Vergleichsstudie. Abschlussbericht zum Projekt S-2007-997-4 der Hans-Böckler-Stiftung. Düsseldorf. [http://www.boeckler.de/pdf_fof/S-2007-997-4-1.pdf, 08.08.2012].

Struck, Olaf; Grotheer, Michael; Schröder, Tim; Köhler, Christoph 2007: Instabile Beschäftigung. Neue Ergebnisse zu einer alten Kontroverse. In: Kölner Zeitschrift für Soziologie und Sozialpsychologie 59,2: 294-317.

Unger, Rainer 2003: Soziale Differenzierung der aktiven Lebenserwartung im internationalen Vergleich. Wiesbaden: Deutscher Universitätsverlag.

WHO 2010: Der Europäische Gesundheitsbericht 2009: Gesundheit und Gesundheitssystem. Kopenhagen Regionalbüro Europa. [http://www.euro.who.int/_data/assets/ pdf_file/0018/82413/E93103g.pdf, 08.08.2012].

Wilkinson, Richard G. 1996: Unhealthy Societies - the Afflictions of Inequality. London: Routledge.

Wilkinson, Richard G.; Marmot, Michael 2003: Social Determinants of Health: The Solid Facts. Copenhagen: WHO Regional Office for Europe.

Wilkinson, Richard G.; Pickett, Kate E. 2006: Income Inequality and Population Health: A Review and Explanation of the Evidence. In: Social Science \& Medicine 62,7: 1768-1784 [doi: 10.1016/j.socscimed.2005.08.036].

Wydler, Hans; Kolip, Petra; Abel, Thomas 2006: Salutogenese und Kohärenzgefühl. Weinheim: Juventa.

Yang, Ming Jen; Yang, Mei-Sang; Kawachi, Ichiro 2001: Work experience and drinking behavior: alienation, occupational status, workplace drinking subculture and problem drinking. In: Public Health 115,4: 265-271 [doi:10.1038/sj.ph.1900761].

Translated from the original text by the Federal Institute for Population Research, for information only. The reviewed and authors' authorised original article in German is available under the title "Wandel der Gesundheitszufriedenheit von Erwerbstätigen", DOI 10.4232/10.CPoS-2013-14de or URN urn:nbn:de:bib-cpos-2013-14de5, at http://www.comparativepopulationstudies.de.

Date of submission: 08.09.2011

Date of Acceptance: 23.05.2012

Prof. Dr. Monika Jungbauer-Gans ( $₫)$. Lehrstuhl für Empirische Wirtschaftssoziologie, Universität Erlangen-Nürnberg, Nürnberg, Germany.

E-Mail: Monika.Jungbauer-Gans@wiso.uni-erlangen.de

URL: http://www.sozialforschung.rw.uni-erlangen.de/lehrstuhlteam/lehrstuhlinhaberin. shtml

Dr. Gerhard Krug. Lehrstuhl für Empirische Wirtschaftssoziologie, Universität ErlangenNürnberg, Nürnberg, Germany. E-Mail: Gerhard.Krug@wiso.uni-erlangen.de URL: http://www.sozialforschung.rw.uni-erlangen.de/lehrstuhlteam/mitarbeiterinnen/ gerhard-krug.shtml Institut für Arbeitsmarkt- und Berufsforschung, Nürnberg, Germany.

E-Mail: gerhard.krug@iab.de

URL: http://www.iab.de/123/section.aspx/Mitarbeiter/207 


\section{Appendix}

Tab. A1: Model comparisons using Wald test, 1985/1996, 1996/2009, in Western and Eastern Germany

\begin{tabular}{lccc}
\hline & $\begin{array}{c}\text { 1985/1996 } \\
\text { West } \\
\text { Coefficient comparison for the variable ... }\end{array}$ & $\begin{array}{c}1996 / 2009 \\
\text { West } \\
\text { p value }\end{array}$ & $\begin{array}{c}1996 / 2009 \\
\text { past }\end{array}$ \\
\hline Age (years) & 0.735 & 0.247 & p value \\
Sex (1, if female) & 0.531 & 0.788 & 0.675 \\
Nationality: non-German (1, if yes) & 0.338 & 0.045 & - \\
Years of education & 0.377 & 0.415 & 0.628 \\
Previous experience with unemployment (in years) & 0.950 & 0.161 & 0.235 \\
Relative poverty (1, if yes) & 0.827 & 0.200 & 0.824 \\
Public sector (1, if yes) & 0.213 & 0.709 & 0.274 \\
Enterprise size 200 to 2,000 employees & 0.609 & 0.299 & 0.522 \\
Enterprise size more than 2,000 employees & 0.659 & 0.857 & 0.006 \\
Actual working hours & 0.370 & 0.018 & 0.063 \\
Job security (1, if no) & 0.134 & 0.032 & 0.618 \\
Worried about economic situation & 0.296 & 0.712 & 0.160 \\
Autonomy low & 0.942 & 0.929 & 0.021 \\
Autonomy medium & 0.826 & 0.615 & 0.060 \\
Autonomy high & 0.220 & 0.778 & 0.461 \\
Autonomy very high & 0.889 & 0.721 & 0.691 \\
Part-time & 0.452 & 0.382 & 0.087 \\
Marginal employment* & 0.691 & 0.536 & 0.003 \\
Fixed-term employed & 0.753 & 0.249 & 0.930 \\
Total & 0.845 & 0.113 & 0.002 \\
\hline
\end{tabular}

Null hypothesis: equality of the coefficients in both years

* Marginal employment is employment below a minimum salary (in 2013: 450 euros per month) with only flatrate social insurance contributions by employers and optional additional contributions by employee.

Source: own calculations, SOEP data 
Tab. A2: Blinder/Oaxaca decomposition of health satisfaction over the course of time 1985/1996, 1996/2009, in Western and Eastern Germany

(Details; absolute: coefficient effects; standard errors in brackets)

\begin{tabular}{|c|c|c|c|}
\hline & $\begin{array}{l}1985 / 1996 \\
\text { West }\end{array}$ & $\begin{array}{l}1996 / 2009 \\
\text { West }\end{array}$ & $\begin{array}{l}1996 / 2009 \\
\text { East }\end{array}$ \\
\hline Mean before & $\begin{array}{l}7.126^{* * *} \\
(0.053)\end{array}$ & $\begin{array}{l}6.902^{* * *} \\
(0.062)\end{array}$ & $\begin{array}{l}6.553^{* * *} \\
(0.084)\end{array}$ \\
\hline Mean after & $\begin{array}{l}6.902^{* * *} \\
(0.062)\end{array}$ & $\begin{array}{l}6.820^{* * *} \\
(0.058)\end{array}$ & $\begin{array}{l}6.618^{* * *} \\
(0.100)\end{array}$ \\
\hline Difference & $\begin{array}{l}-0.224^{* * *} \\
(0.077)\end{array}$ & $\begin{array}{r}-0.082 \\
(0.083)\end{array}$ & $\begin{array}{r}0.065 \\
(0.128)\end{array}$ \\
\hline $\begin{array}{l}\text { Decomposition of difference } \\
\text { Total explained }\end{array}$ & $\begin{array}{c}\text { absolute } \\
-0.098^{* *} \\
(0.038)\end{array}$ & $\begin{array}{c}\text { absolute } \\
-0.095^{* *} \\
(0.040)\end{array}$ & $\begin{array}{c}\text { absolute } \\
-0.084 \\
(0.068)\end{array}$ \\
\hline \multicolumn{4}{|l|}{ Control variables } \\
\hline Age(years) & $\begin{array}{l}-0.062^{* * *} \\
(0.021)\end{array}$ & $\begin{array}{l}-0.082 * * * \\
(0.021)\end{array}$ & $\begin{array}{l}-0.065^{* *} \\
(0.031)\end{array}$ \\
\hline Sex (1, if female) & $\begin{array}{r}0.003 \\
(0.005)\end{array}$ & $\begin{array}{r}0.006 \\
(0.011)\end{array}$ & $\begin{array}{r}0.003 \\
(0.013)\end{array}$ \\
\hline Nationality: non-German ( 1 , if yes) & $\begin{array}{r}-0.002 \\
(0.005)\end{array}$ & $(0.006)$ & $\begin{array}{ll}- \\
-\end{array}$ \\
\hline Years of education & $\begin{array}{r}0.013 \\
(0.012)\end{array}$ & $\begin{array}{l}0.052^{* *} \\
(0.020)\end{array}$ & $\begin{array}{r}-0.004 \\
(0.015)\end{array}$ \\
\hline \multicolumn{4}{|l|}{ Structural variables } \\
\hline $\begin{array}{l}\text { Previous experience with unemployment } \\
\text { (in years) }\end{array}$ & $\begin{array}{l}-0.022^{*} \\
(0.012)\end{array}$ & $\begin{array}{r}0.000 \\
(0.005)\end{array}$ & $\begin{array}{l}-0.069^{* *} \\
(0.031)\end{array}$ \\
\hline Relative poverty ( 1 , if yes) & $\begin{array}{r}0.001 \\
(0.003)\end{array}$ & $\begin{array}{r}-0.005 \\
(0.006)\end{array}$ & $\begin{array}{r}0.018 \\
(0.017)\end{array}$ \\
\hline Public sector ( 1 , if yes) & $\begin{array}{r}0.002 \\
(0.003)\end{array}$ & $\begin{array}{r}0.008 \\
(0.007)\end{array}$ & $\begin{array}{r}0.008 \\
(0.014)\end{array}$ \\
\hline \multicolumn{4}{|l|}{ Enterprise size } \\
\hline Less than 200 employees & $\begin{array}{r}-0.000 \\
(0.001)\end{array}$ & $\begin{array}{r}0.002 \\
(0.003)\end{array}$ & $\begin{array}{r}-0.005 \\
(0.007)\end{array}$ \\
\hline 200 to 2,000 employees & $\begin{array}{r}0.000 \\
(0.000)\end{array}$ & $\begin{array}{r}0.002 \\
(0.002)\end{array}$ & $\begin{array}{r}-0.001 \\
(0.003)\end{array}$ \\
\hline More than 2,000 employees & $\begin{array}{r}-0.000 \\
(0.002)\end{array}$ & $\begin{array}{r}-0.001 \\
(0.003)\end{array}$ & $\begin{array}{r}-0.001 \\
(0.003)\end{array}$ \\
\hline Actual working hours & $\begin{array}{r}0.005 \\
(0.007)\end{array}$ & $\begin{array}{r}-0.009 \\
(0.006)\end{array}$ & $\begin{array}{r}0.004 \\
(0.015)\end{array}$ \\
\hline Job security ( 1 , if no) & $\begin{array}{l}-0.064^{* * *} \\
(0.023)\end{array}$ & $\begin{array}{r}-0.021 \\
(0.014)\end{array}$ & $\begin{array}{r}0.016 \\
(0.013)\end{array}$ \\
\hline Worried about economic situation & $\begin{array}{r}0.007 \\
(0.009)\end{array}$ & $\begin{array}{l}-0.048^{* * *} \\
(0.015)\end{array}$ & $\begin{array}{r}-0.031 \\
(0.019)\end{array}$ \\
\hline
\end{tabular}


Continuation Tab. A2

\begin{tabular}{lrrr}
\hline & $1985 / 1996$ & $1996 / 2009$ & $1996 / 2009$ \\
& West & West & East \\
\hline Occupational autonomy & & & \\
Very low & 0.003 & 0.003 & 0.000 \\
Low & $(0.003)$ & $(0.004)$ & $(0.008)$ \\
& 0.004 & -0.001 & 0.020 \\
Medium & $(0.005)$ & $(0.002)$ & $(0.014)$ \\
High & -0.001 & -0.000 & -0.010 \\
& $(0.002)$ & $(0.001)$ & $(0.013)$ \\
Very high & 0.009 & 0.000 & -0.008 \\
& $(0.005)$ & $(0.002)$ & $(0.012)$ \\
Employment status & 0.000 & 0.002 & -0.004 \\
Full-time & $(0.001)$ & $(0.002)$ & $(0.007)$ \\
& & & \\
Part-time & 0.005 & -0.008 & 0.019 \\
Marginal employment & $(0.008)$ & $(0.010)$ & $(0.019)$ \\
& 0.003 & 0.002 & 0.004 \\
Fixed-term employed & $(0.006)$ & $(0.004)$ & $(0.017)$ \\
& 0.000 & -0.007 & 0.005 \\
Unexplained (coefficient effects) & $(0.003)$ & $(0.009)$ & $(0.011)$ \\
Number of cases & -0.000 & 0.011 & 0.017 \\
\hline
\end{tabular}

Note: ${ }^{*} p<0.10,{ }^{*} p<0.05,{ }^{* *} p<0.01$. In the regression estimations that served as the basis for the decomposition, in Eastern Germany employees of non-German nationality were not included since the low cell numbers led to estimation problems.

Source: own calculations, SOEP data 


\section{Comparative Population Studies - Zeitschrift für Bevölkerungswissenschaft}

wWw.comparativepopulationstudies.de

ISSN: 1869-8980 (Print) - 1869-8999 (Internet)

Published by / Herausgegeben von

Prof. Dr. Norbert F. Schneider

Federal Institute for Population Research

D-65180 Wiesbaden / Germany

Managing Editor /

Verantwortlicher Redakteur

Frank Swiaczny

Assistant Managing Editor /

Stellvertretende Redakteurin

Katrin Schiefer

Language \& Copy Editor (English) /

Lektorat \& Übersetzungen (englisch)

Amelie Franke

Copy Editor (German) /

Lektorat (deutsch)

Dr. Evelyn Grünheid

\section{Layout / Satz}

Beatriz Feiler-Fuchs

E-mail: cpos@bib.bund.de

\author{
Scientific Advisory Board / \\ Wissenschaftlicher Beirat \\ Jürgen Dorbritz (Wiesbaden) \\ Paul Gans (Mannheim) \\ Johannes Huinink (Bremen) \\ Marc Luy (Wien) \\ Clara H. Mulder (Groningen) \\ Notburga Ott (Bochum) \\ Peter Preisendörfer (Mainz)
}

\section{Board of Reviewers / Gutachterbeirat} Martin Abraham (Erlangen)

Laura Bernardi (Lausanne) Hansjörg Bucher (Bonn) Claudia Diehl (Göttingen) Andreas Diekmann (Zürich) Gabriele Doblhammer-Reiter (Rostock) Henriette Engelhardt-Wölfler (Bamberg) E.-Jürgen Flöthmann (Bielefeld) Alexia Fürnkranz-Prskawetz (Wien) Beat Fux (Zürich) Joshua Goldstein (Rostock) Karsten Hank (Köln) Sonja Haug (Regensburg) Franz-Josef Kemper (Berlin) † Michaela Kreyenfeld (Rostock) Aart C. Liefbroer (Den Haag) Kurt Lüscher (Konstanz) Dimiter Philipov (Wien) Tomáš Sobotka (Wien) Heike Trappe (Rostock) 